\title{
Auditor Information Spillovers and Company Operating Performance: Evidence from Targeted Auditor Switches
}

\section{By: Tyler Kleppe}

\begin{abstract}
In this study, I examine whether companies realize operational benefits from making "targeted auditor switches" (i.e., engaging a new auditor recently dismissed by a competitor company). While prior work provides evidence consistent with companies perceiving that auditor information spillovers are costly, there is sparse extant evidence as to whether auditors actually do transfer operational information across companies. I find that companies that switch to a competitor's former auditor realize significant subsequent improvements in operating performance and that the association between targeted auditor switches and improvements in operating performance varies predictably with several across- and within-market factors. In addition, I document systematic movement in local audit markets consistent with a recognition of the value of auditors' operational knowledge. Finally, I find that companies that make targeted switches pay a significant audit fee premium to the incoming auditor and that this premium does not appear to be attributable to these companies hiring higher-quality auditors. Collectively, my findings suggest that operational information can be transferred across companies via external auditors and that companies' concerns over sharing an auditor with a competitor are based on real information spillover costs.
\end{abstract}

Keywords: auditor information spillovers; auditor selection; operational value of auditor knowledge

Data Availability: All data used are publicly available from sources cited in the text. 


\section{Introduction}

In this study, I examine whether companies realize operational benefits from engaging a new auditor recently dismissed by a competitor company. Given the broad scope of a public company audit and the nature of the auditing process, external auditors become privy to an array of proprietary client information. ${ }^{1}$ Under Rule 301 of the AICPA's Code of Professional Conduct, auditors are explicitly restricted from disclosing any confidential client information without the consent of the client (AICPA 2013). ${ }^{2}$ However, despite auditors' codified obligation to protect sensitive client information, there is considerable extant evidence suggesting that companies are reluctant to share an auditor with a competitor company over concerns of proprietary information spillovers (e.g., Tierney 1989; Berton and Niebuhr 1990; Aobdia 2015; Bills, Cobabe, Pittman, and Stein 2020; Kang, Lennox, and Pandey 2020).

The potential benefits (and costs) of auditor information spillovers are considerable given that the information accumulated by an auditor is not necessarily limited to a client's financial reporting function. ${ }^{3}$ Consistent with this, KPMG's Global Head of Audit Larry Bradley recently stated as part of the firm's "Value of Audit" report that, "we [as auditors] have broader access to a company than almost any other entity or profession. I've been an audit partner my entire career, and in that role you look across so many different things-IT, HR, legal, compliance, finance, control, etc." (KPMG 2014, p. 4). In the same report, KPMG's US Head of Audit Jim Liddy remarked that, "we [as auditors] also add value by delivering insight and perspective across a wide

\footnotetext{
${ }^{1}$ The term "proprietary information" is generally defined as any information that a company protects against disclosure and that adds commercial value to the company (e.g., Dye 1986). While items such as customer lists, trade secrets, and formulae are often presented as examples of proprietary information, many other types of information can be considered proprietary including company policies and procedures, operational processes, technical know-how, and business strategies. For purposes of this study, I consider proprietary information to include any company information that, if disclosed, would be potentially beneficial to the operations of the company's competitors.

${ }^{2}$ The full text of Rule 301 is presented in Appendix A.

${ }^{3}$ Auditor information spillovers represent a potential cost to the company whose information is being transferred and a potential benefit to the company (or companies) to which the information is being transferred.
} 
array of financial, regulatory, operational and technology topics" (KPMG 2014, p. 10). Consistent with these practitioners' views, auditors have ample opportunities to gain insights into client operations through activities such as internal control audit procedures (e.g., walk-throughs, interviews, observations), risk assessment procedures (e.g., obtaining an understanding of the client's competitive environment and technological developments), and certain agreed-upon procedures (PCAOB 2007, 2010a; Cai, Kim, Park, and White 2016). ${ }^{4}$ Auditors also often accumulate information related to clients' operations through informal discussions with management and other company personnel (Cai et al. 2016; Dhaliwal, Lamoreaux, Litov, and Neyland 2016) and provide operational suggestions to clients via these same types of discussions as well as through other channels such as management letters (Eilifsen, Knechel, and Wallage 2001). In addition, evidence from prior work suggests that company managers' discretionary decisions can be influenced by the company's auditor (Aobdia 2015) and that auditors generally know more about a client's business operations than any other outside party (SEC 2000). ${ }^{5}$

A potential reason why companies are reluctant to share an auditor with a competitor is that the opportunity for the transfer of proprietary information via the auditor exists even in the absence of explicit leakages. Auditors' use of "best practices" represents one likely mechanism for the indirect transfer of proprietary knowledge across clients. Best practices represent an “institutionalized channel for information spillovers in auditing" (Aobdia 2015, p. 1509) and often include benchmarks that are formulated by the auditor and communicated across clients. While

\footnotetext{
${ }^{4}$ As stated in PCAOB Auditing Standard (AS) 2101 on Audit Planning, when developing the audit strategy and audit plan, auditors are required to consider "matters relating to the company's business, including its organization, operating characteristics, and capital structure" (emphasis added) (PCAOB 2010a).

${ }^{5}$ In a comment letter to the SEC, Deloitte states that "[a company's auditor is] often more knowledgeable about a company's financial systems, internal controls and business operations than anyone else both from the standpoint of experience with a number of companies in the industry as well as with the audit client in particular. This experience yields state of the art knowledge about the client, its systems and its needs, that is more efficiently transferred to other individuals within the same accounting firm, than to third parties with no previous exposure to the companies' business" (SEC 2000, p. 24).
} 
information spillovers through best practices are by nature indirect, auditors can transfer client information either intentionally or unintentionally using this mechanism (Cashell and Fuerman 1995; Cahan, Godfrey, Hamilton, and Jeter 2008). In addition, unlike the explicit disclosure of confidential client information, auditors are not restricted from employing the use of best practices and, in some cases, are actually encouraged to do so (McAllister and Cripe 2008; AICPA 2013; PCAOB 2018).

Recent work finds that companies are reluctant to share an auditor (or a specific audit partner) with a rival company due to information spillover concerns and that this reluctance is more prominent when the costs of information leakage are higher (Aobdia 2015; Bills et al. 2020; Kang et al. 2020). While these papers provide evidence consistent with companies perceiving that auditor information spillovers are costly (and conversely beneficial for companies on the receiving end of the spillovers), little extant evidence exists as to whether there are operational consequences of auditor information transfer. ${ }^{6}$ I fill this void in the literature by examining "targeted auditor switches" (i.e., auditor switches where the company making the switch subsequently selects an auditor that was dismissed by (or resigned from) one of the company's local market competitors in the immediately preceding period). In doing so, I attempt to determine whether there are operational benefits associated with engaging a competitor's former auditor and, consequently, whether concerns over auditor sharing are based on real information spillover costs or merely the perception of spillover costs.

Using two measures of operating performance, I test the relation between targeted auditor switches and subsequent changes in company operating performance. The results of these tests

\footnotetext{
${ }^{6}$ There is extant evidence suggesting that auditor knowledge spillovers (through the joint provision of audit and nonaudit services) lead to improvements in audit and financial reporting quality (e.g., Lim and Tan 2008; Christensen, Olson, and Omer 2015).
} 
reveal that companies that make targeted auditor switches realize superior improvements in operating performance relative to both companies that do not switch auditors and companies that make non-targeted switches. These improvements are economically significant. Specifically, the estimated increase in two-year operating income growth (operating cash flow growth) for companies that make targeted switches is approximately 19.3 percent (16.0 percent) of the interquartile range of each measure, respectively. These results suggest that targeted auditor switches on average yield significant operational benefits, presumably (at least in part) through auditor information spillovers.

To support this interpretation of the primary results, I next perform a series of crosssectional analyses. I consider both across-market (i.e., industry- or geographic-level) factors and within-market (i.e., company-level) factors that are likely to influence the relation between targeted auditor switches and operating performance improvements. The first factor I consider is industry concentration. Ali, Klasa, and Yeung (2014) posit that proprietary costs are higher in more concentrated industries because companies in these industries generally have more restrictive disclosure policies. Consistent with the primary results being attributable to spillovers of proprietary information via the auditor, I find that the association between targeted auditor switches and changes in operating performance is increasing in industry concentration.

The second factor I consider is the strength of non-compete agreement enforcement. The strength of the enforceability of non-compete agreements has been shown to affect the likelihood of information spillover occurring through hiring individuals employed by a market competitor (Belenzon and Schankerman 2013). Consistent with targeted auditor switches being a more viable option for companies seeking beneficial information spillover in the presence of stronger noncompete enforcement, I find that the positive association between targeted switches and changes 
in operating performance is greater for companies headquartered in states with relatively strong non-compete enforcement.

The third factor I consider is auditor liability exposure. Prior work documents that auditors consider potential liability exposure when making client acceptance decisions (Anantharaman, Pittman, and Wans 2016; Honigsberg, Rajgopal, and Srinivasan 2019) and that this sensitivity to litigation risk is likely to be heightened in instances where a prospective client is a close competitor of a former client. Consistent with auditors being more cautious to avoid actual or perceived spillovers of client-specific information in the presence of greater liability exposure, I find that the positive relation between targeted auditor switches and changes in operating performance is reduced in markets where auditor liability exposure is relatively high.

The fourth and final cross-sectional factor I consider is the extent of a company's assets that are made up of inventory (i.e., inventory intensity). One likely mechanism for spillovers of clients' “operational information" (Mobbs 2013) is through auditors' knowledge of clients' inventory management systems. Auditors are required to develop a deep understanding of clients' inventory processes (Bhattacharjee, Moreno, and Riley 2012; Feng, Li, McVay, and Skaife 2015), and extant evidence suggests that internal controls over inventory management have a significant impact on firm operations (Feng et al. 2015). ${ }^{7}$ Consistent with the operational value of auditors' knowledge being relatively higher for inventory-intensive clients, I find that the association between targeted auditor switches and changes in operating performance is increasing in companylevel inventory intensity.

Next, I investigate whether there is systematic movement (i.e., auditor-client realignments)

\footnotetext{
${ }^{7}$ Inventory is often one of the highest-risk audit areas for both financial statement audits and internal control audits, and auditors must develop a deep and holistic understanding of clients' inventory management systems in order to reduce the risk of audit failure related to inventory (Hay, Knechel, and Wong 2006; PCAOB 2010b; Feng et al. 2015).
} 
in local audit markets consistent with a recognition of the value of auditors' operational knowledge. If companies recognize the potential operational value of switching to an auditor formerly engaged with a local market competitor (as suggested by the primary results), then I expect that these types of switches will occur with abnormal frequency. Specifically, I predict that companies will be more likely to switch to an auditor formerly engaged with a local market competitor if a competitor switches auditors in the preceding period, since this presents the opportunity to engage an auditor with extensive knowledge of a competitor while avoiding any auditor sharing costs. Consistent with this, I find that companies are more likely to switch auditors following a prior-period competitor auditor switch, but only when the subsequently selected auditor was formerly engaged with a competitor company.

Finally, I examine the association between targeted auditor switches and both audit pricing and auditor quality. Prior work documents that companies that switch auditors generally receive an initial audit fee discount from the incoming auditor. However, given that targeted switches are associated with subsequent improvements in operating performance, I expect that the agreed-upon price of the audit will reflect the value of these improvements. Consistent with this, I find that companies that make targeted auditor switches on average do not receive an audit fee discount from the incoming auditor. In fact, these companies actually pay a substantial premium to the new auditor, consistent with the value of targeted auditors' knowledge being impounded into the price of the audit. While I attribute this audit fee premium to the association between targeted switches and subsequent improvements in operating performance, a possible alternative explanation is that companies making targeted switches are motivated by a desire for higher auditor quality. However, I find no evidence that companies making targeted switches subsequently select higher-quality auditors. In fact, I find that these companies on average subsequently select auditors with greater 
preceding audit failure rates relative to both companies making non-targeted switches and companies that do not switch auditors.

This study contributes to the literatures on auditor information spillovers and audit (auditor) value. First, I provide evidence suggesting that information is transferred across companies via external auditors and that auditor information spillovers are associated with significant operational benefits for the companies to which the information is likely being transferred. Specifically, the results reveal that companies that make targeted auditor switches realize significant subsequent improvements in both operating income and operating cash flows and that the association between targeted switches and improvements in operating performance varies predictably with several across- and within-market factors. More broadly, the collective evidence in this paper suggests that the value of an audit (auditor) is associated with the auditor's informational capital and extends beyond that which is traditionally considered by investors and other capital market participants (Healy and Palepu 2001). ${ }^{8}$ Given that auditors accumulate more information about their clients than arguably any other external party (SEC 2000; KPMG 2014), my findings should be of interest to wide range of stakeholders, including managers, board members, investors, and regulators.

Second, the results of this study suggest that companies' concerns over sharing an auditor with a competitor are justified. Recent work on auditor-related information spillovers generally finds that companies are reluctant to share an auditor with a competitor due to concerns over proprietary information leakage. I add to this literature by documenting that companies appear to target auditors that are likely to hold proprietary information related to their competitor(s) and that

\footnotetext{
${ }^{8}$ Traditional views of the value of an audit (auditor) focus primarily on the value of the financial statement audit and the value of the auditor's public communications (e.g., the issuance of a going concern opinion or other modified language in the audit report) (Healy and Palepu 2001; DeFond and Zhang 2014).
} 
the ex post consequences associated with these targeted auditor switches are consistent with the transfer of operational information through the auditor. While my research design differs from related studies in that I do not examine concurrent auditor sharing between competitor companies, my results suggest that concerns over auditor sharing are likely based on real information spillover costs and that these costs are potentially relevant to the auditor selection process.

\section{Background and Hypothesis Development}

There is considerable anecdotal evidence suggesting that companies have concerns about their proprietary information being shared with competitors via their auditor. For example, following the merger of Ernst \& Whinney (Coca-Cola's auditor) with Arthur Young (PepsiCo's auditor), Ernst and Young resigned as PepsiCo's auditor due to Coca-Cola's concerns over sharing an auditor with a major competitor (Berton and Niebuhr 1990; Cowan 1990). In addition, Frederick Zuckerman, the former treasurer of Chrysler, echoed a similar sentiment in stating that, "It' $d$ be very awkward to have the same auditor for two large firms...Clients may feel uncomfortable knowing that their corporate secrets are lying just a few files away from papers of their arch rivals" (Tierney 1989). These concerns are not unique to the auditor-client setting. Prior work in the management literature documents that companies are reluctant to join industry trade groups over fears of proprietary information leakage to competitors (Grindley, Mowery, and Silverman 1994). There is also considerable extant research on proprietary information acquisition and sharing by suppliers, both for suppliers of tangible goods and suppliers of services ( $\mathrm{Li}$ and Lin 2006; Sengupta, Heiser, and Cook 2006; Anand and Goyal 2009; Kong, Rajagopalan, and Zhang 2013; Tan, Wong, and Chung 2016).

Despite the anecdotal evidence described above, there is relatively little empirical evidence 
on the existence or consequences of auditors' leakages of proprietary client information. ${ }^{9}$ Aobdia (2015) documents that companies are reluctant to share an auditor with a rival due to concerns over information spillover. Additionally, Bills et al. (2020) document that, despite the potential benefits of sharing an auditor with an industry peer, companies are reluctant to share an auditor in settings where the costs of information leakage to competitors are higher. In a concurrent working paper, Kang et al. (2020) examine information spillover concerns at the audit partner level and find that rival companies are less likely to share the same partner when they are more concerned about potential information spillovers. While these studies focus on companies' concerns over concurrent auditor sharing, I investigate auditor information spillovers using a setting where the potential costs of concurrent auditor sharing are nonexistent. An advantage of my setting is that I avoid any potential selection bias that is likely to exist when two competitor companies concurrently share the same auditor. Selection bias could affect the inferences of studies that examine concurrent auditor sharing because in these instances both companies make the choice to engage the same auditor in the same period. Another challenge in studying concurrent auditor sharing is that competitor companies that concurrently share an auditor are simultaneously exposed to both the costs and benefits of auditor information spillovers.

The studies outlined in the preceding paragraph generally find that companies are reluctant to share an auditor when the perceived risk of information spillover is greater and infer that companies' reluctance over auditor sharing is based on the concern that, given their unique access to client information, auditors have the opportunity to facilitate the transfer of this sensitive information to the benefit of a competitor company. In a similar vein, McAllister and Cripe (2008)

\footnotetext{
${ }^{9}$ Case law reveals that auditors have faced legal actions related to the transfer of sensitive client information. In one well-publicized case (Consolidata Services v. Alexander Grant), Grant Thornton was prosecuted after it was determined that the firm shared information related to the operations of one client to its other clients (Werner 2009).
} 
note that auditors often accumulate proprietary information about clients and have ample opportunities to pass this information to other clients. Furthermore, in contrast to the explicit sharing of client secrets, the use of "best practices" provides auditors with an institutionalized channel for information transfer. ${ }^{10}$

To test for evidence of auditor information spillovers, I identify instances where a company switches to an auditor that was dismissed by (or resigned from) a local market competitor company in the immediately preceding period. In these cases, the opportunity to benefit from an auditor's proprietary knowledge is relatively greater (e.g., companies making these types of switches can subsequently interact with audit personnel that are likely to have in-depth knowledge of a close market competitor), and the potential costs of concurrent auditor sharing are nonexistent (because the selected auditor is no longer engaged with the competitor company). I refer to these types of switches as "targeted auditor switches" since switching to a specific auditor that just ended a relationship with a local market competitor company is suggestive of an intent (at least in some cases) to benefit from auditor information spillovers. ${ }^{11}$

If a company switches auditors, it stands that the company considers the expected benefits of the switch to outweigh the expected costs of the switch. As suggested above, one potential benefit of a targeted auditor switch is the opportunity to acquire proprietary competitor information via the incoming auditor. Auditors have unique access to client information and often develop a

\footnotetext{
${ }^{10} \mathrm{McDonald}$ (2013) provides further insights into the use of best practices as a channel for information transfer by professional service providers in his book on the management consulting firm McKinsey \& Company. McDonald (2013, p. 5) states: "McKinsey offers a kind of industrial espionage couched in the language of 'best practices.' Want to know what the competition is up to? Hire McKinsey. After all, it's working with everyone else as well. The flip side of that argument is that your competitors find out about you too." The recent shift by accounting firms towards an increased emphasis on consulting services (Lisic, Myers, Pawlewicz, and Seidel 2019; Cowle, Kleppe, Moon, and Shipman 2019) likely increases the opportunity for this form of information transfer as accounting firms accumulate even more proprietary client information.

${ }^{11}$ I acknowledge that not all switches I define as targeted switches are necessarily made with the explicit intent to benefit from auditor information spillovers.
} 
deep understanding of their clients' operations, strategic plans, and competitive forces (Fontaine, Letaifa, and Herda 2013; KPMG 2014; Cai et al. 2016). ${ }^{12}$ Furthermore, extant evidence suggests that this information can be shared (either intentionally or unintentionally) across an auditor's portfolio of clients (Cahan et al. 2008; Werner 2009; Rapoport 2013). Importantly, prior research also provides several reasons to expect that the value of any auditor information spillovers could extend beyond a client's financial reporting function into the operational aspects of the client's business. First, prior work documents that auditors have broad access to client operations and often provide suggestions to clients regarding operational issues (Eilifsen et al. 2001; KPMG 2014; Cai et al. 2016). Second, Aobdia (2015) provides evidence suggesting that company managers' discretionary decisions (e.g., decisions related to company operations) can be influenced by the company's auditor. Finally, given the depth of knowledge that is necessary to satisfactorily conduct a public company audit in the current regulatory regime, auditors arguably know more about a client's operations than any other outside party (SEC 2000; PCAOB 2010a; KPMG 2014). Accordingly, I expect that companies that make targeted auditor switches on average will benefit from auditor information spillovers in the form of subsequent improvements in operating performance. Specifically, my primary hypothesis is stated as follows (in alternative form):

Hypothesis: Companies that make "targeted auditor switches" realize greater subsequent improvements in operating performance relative to both companies that do not switch auditors and companies that make non-targeted auditor switches.

Although I predict that targeted auditor switches will be associated with significant improvements in operating performance, there are reasons why this prediction may not hold. First,

\footnotetext{
${ }^{12}$ For example, an anonymous CFO surveyed by Fontaine et al. (2013, p. A10) made the following statement in regards to the external auditor's involvement in the company's strategic planning: "We will discuss our strategy [with our auditor]. This is an occasion to demonstrate that [our auditor] takes to heart what happens in our company." The same CFO also stated that the auditor does this "to better understand our company and our business" (Fontaine et al. 2013, p. A11).
} 
liability risk is often a significant concern for auditors (Laux and Newman 2010; Anantharaman et al. 2016; Honigsberg et al. 2019), and the possibility of substantial legal costs resulting from accusations (whether substantiated or not) of violations of client confidentiality could motivate auditors to establish safeguards to prevent any leakages of proprietary client information. Additionally, it is possible that any informational capital held by a targeted auditor is only beneficial to the client insofar as it helps to improve the client's financial reporting function. In this case, I would not expect to find an association between targeted auditor switches and subsequent improvements in operating performance.

\section{Research Methodology and Sample}

\subsection{Test of Primary Hypothesis}

To investigate the relation between targeted auditor switches and subsequent changes in company operating performance, I estimate the following equation:

$$
\begin{aligned}
& \triangle \text { OPPerf }_{t+2, t}=\delta_{0}+\delta_{1} \text { TargetSwitch }_{t}+\delta_{2} \text { OtherSwitch }_{t}+\delta_{3} \text { Age }_{t}+\delta_{4} \text { Cash }_{t}+\delta_{5} \text { CEOChange }_{t} \\
& \quad+\delta_{6} \text { DiscAcc }_{t}+\delta_{7} \text { GoingConcern }_{t}+\delta_{8} \text { Growth }_{t}+\delta_{9} \text { InvRec }_{t}+\delta_{10} \text { Leverage }_{t} \\
& \quad+\delta_{11} \text { Loss }_{t}+\delta_{12} M \& A_{t}+\delta_{13} \text { ModOpinion }_{t}+\delta_{14} \text { ROA }_{t}+\delta_{15} \text { Size }_{t}+\text { Industry FE } \\
& \quad+\text { Year FE } \\
& \quad \varepsilon
\end{aligned}
$$

The dependent variable in Equation (1) is $\triangle O p P e r f$, which represents one of two proxies for changes in company operating performance. Following Barber and Lyon (1996), I define the first proxy as $\Delta O P I n c$, the two-year change in the company's operating income scaled by average total assets. As articulated in Barber and Lyon (1996), operating income is a reliable proxy for operating performance because it is not obscured by special items, tax considerations, and other non-operating items and therefore provides a clean measure of the productivity of operating assets. The second proxy is $\triangle O p C F$, the two-year change in the company's operating cash flows scaled by average total assets (Wasley and $\mathrm{Wu} 2006$ ). I measure the changes in operating performance over a two-year period because I expect that any meaningful improvements in operating 
performance are not likely to materialize immediately following an auditor switch, especially for switches occurring later in a fiscal year. Moreover, a two-year measurement window is consistent with prior studies that examine changes in operating performance following major corporate events (e.g., IPOs, M\&A activity, increases in executive stock ownership) (Kaplan 1989; Degeorge and Zeckhauser 1993; Core and Larcker 2002).

The two variables of interest are TargetSwitch and OtherSwitch. TargetSwitch is an indicator variable equal to one if the company switches auditors and the incoming auditor was dismissed by (or resigned from) one of the company's local market (based on metropolitan statistical area (MSA) and two-digit SIC industry) competitors in the preceding period, and zero otherwise. OtherSwitch is an indicator variable equal to one for all other auditor switches. I define markets based on MSA and industry for two reasons. First, prior work documents that auditors compete at the city-industry level (Francis, Reichelt, and Wang 2005; Numan and Willekens 2012; Chu, Simunic, Ye, and Zhang 2018). Second, I expect auditor information spillovers to be more prevalent at the local market level, primarily due to a higher likelihood of overlap in audit team personnel. My primary hypothesis predicts that the coefficient on TargetSwitch ${ }_{t}\left(\delta_{1}\right)$ will be positive (i.e., targeted switches will be associated with greater improvements in operating performance relative to non-switches) and that $\delta_{l}$ will be more positive than the coefficient on OtherSwitch ${ }_{t}\left(\delta_{2}\right)$ (i.e., targeted switches will be associated with greater improvements in operating performance relative to other switches).

The control variables included in Equation (1) are based on prior research that examines auditor switches (e.g., Landsman, Nelson, and Rountree 2009) and changes in company operating performance (e.g., Kim, Kitsabunnarat, and Nofsinger 2004; Blackwell, Dudney, and Farrell 2007). Specifically, I control for several company characteristics including age (Age), cash on hand 
(Cash), growth (Growth), leverage (Leverage), current financial performance (Loss, ROA), and total assets (Size). I also control for several audit risk factors including financial reporting quality (DiscAcc), the ratio of inventory and receivables to total assets (InvRec), and whether the company receives a going concern opinion (GoingConcern) or some other modified audit opinion (ModOpinion). Additionally, I include controls for whether the company reports merger and/or acquisition activity $(M \& A)$ and whether the company experiences executive turnover (CEOChange). Finally, I include two-digit SIC industry and fiscal year fixed effects. ${ }^{13}$

\subsection{Sample}

The primary sample consists of company-year observations spanning fiscal years 2002 through 2016. I begin the sample period in 2002 as this is the first year with complete data necessary for my empirical tests. ${ }^{14}$ The sample period ends in 2016 to allow sufficient time to calculate the two-year changes in operating performance discussed in Section 3.1. I obtain financial statement and other company data from Compustat and auditor-related data from Audit Analytics. The sample selection process is outlined in Table 1. I begin with a sample of 94,781 company-year observations, which represents the intersection of Compustat and Audit Analytics for the full sample period. Next, I delete observations without necessary data for the construction of the test and control variables. Finally, I limit the sample to MSA-industry-years with at least three observations. I impose this restriction to ensure that each company-year in the sample has a reasonable "opportunity" to make a targeted auditor switch (i.e., without sufficient local market competition in a given year, a company is precluded from making a targeted switch). ${ }^{15}$ After

\footnotetext{
${ }^{13}$ Although I use robust regression as the primary specification for estimations of Equation (1) (see Section 4.2), I winsorize all continuous variables at the 1st and 99th levels to reduce the effects of outliers for all descriptive analyses and OLS regression analyses. However, inferences from these analyses are unchanged if I do not winsorize.

${ }^{14}$ To ensure that my inferences are not affected by the implementation of the Sarbanes-Oxley Act (SOX), I re-estimate each of my tests after excluding observations before fiscal year 2004. My inferences are unchanged throughout.

${ }^{15}$ My inferences are not contingent on this design choice. Specifically, if I re-estimate each of my tests without this sample restriction, my inferences are unchanged throughout.
} 
implementing these restrictions, the final sample consists of 27,644 company-year observations.

\section{Empirical Results}

\subsection{Descriptive Statistics and Correlations}

Descriptive statistics for the full sample are presented in Table 2. The mean rate of auditor switches in the sample is approximately eight percent (sum of TargetSwitch $t$ and OtherSwitch ), and targeted switches represent just over one-half percent of the full sample and over six percent of all switches. ${ }^{16}$ The mean (median) two-year change in operating income is $-0.009(-0.001)$, and the mean (median) two-year change in operating cash flows is $-0.007(-0.002)$. These values suggest that both proxies for changes in operating performance are distributed around zero in the full sample. The distributions of the remaining variables are in line with expectations and generally consistent with prior literature.

Pearson pairwise correlation coefficients for the variables employed in the study are presented in Table 3. Coefficients reported in bold and italics are significant at the ten percent level. As shown, there is a positive and significant correlation between targeted auditor switches (TargetSwitch $)$ and both changes in operating income $\left(\Delta O p I n c_{t+2, t}\right)$ and changes in operating cash flows $\left(\triangle O p C F_{t+2, t}\right)$, providing initial univariate evidence in support of my primary hypothesis. Conversely, the correlations between non-targeted switches (OtherSwitch ${ }_{t}$ ) and both measures of changes in operating performance are negative but not statistically significant.

\subsection{Test of Primary Hypothesis}

The results of the estimations of Equation (1) used to test the relation between targeted auditor switches and changes in operating performance are presented in Table 4. Given the

\footnotetext{
${ }^{16}$ The eight percent switch rate is slightly higher than the rates in some prior papers on auditor switches. This is due in part to the sample restriction I impose that requires each MSA-industry-year to have at least three observations. Without this restriction, the mean rate of auditor switches is more comparable to prior work. Again, my inferences are unchanged if this sample restriction is not imposed.
} 
relatively low number of "treatment" observations (i.e., targeted switch observations), I follow Ryan, Tucker, and Zhou (2016) and Kelly, Presslee, and Webb (2017) and estimate these tests using robust regression to ensure that my results are not unduly affected by influential observations. ${ }^{17}$ This design choice is also consistent with the recommendation of Leone, MinuttiMeza, and Wasley (2019), who document that robust regression outperforms other approaches in addressing the effects of influential observations.

Column (1) of Table 4 presents the results of estimations of Equation (1) with changes in operating income $\left(\Delta O P \operatorname{Inc} c_{t+2, t}\right)$ as the dependent variable, and Column (2) presents the results with changes in operating cash flows $\left(\triangle O P C F_{t+2, t}\right)$ as the dependent variable. The variables of interest are TargetSwitch ${ }_{t}$ and OtherSwitch $_{t}$. As reported, the coefficient on TargetSwitch ${ }_{t}$ is positive and significant in each estimation ( $p<0.01$ in both Columns), suggesting that companies that make targeted auditor switches realize greater subsequent improvements in operating performance relative to companies that do not switch auditors. The coefficient on OtherSwitch is insignificant in each case. In addition, I report the tests of the difference in the coefficients on TargetSwitch ${ }_{t}$ and OtherSwitch $t_{t}$ at the bottom of Table 4. As shown, the coefficient on TargetSwitch is significantly greater than the coefficient on OtherSwitch $_{t}$ in each estimation $(\mathrm{p}<0.01$ in Column $1 ; \mathrm{p}<0.05$ in Column 2). This suggests that companies that make targeted switches also realize greater subsequent improvements in operating performance relative to companies that make nontargeted switches, therefore providing evidence that the association between targeted switches and changes in operating performance is not attributable to auditor switches in general. Economically, the estimated increase in two-year operating income growth (operating cash flow growth) for companies that make targeted switches is approximately 19.3 percent (16.0 percent) of the

\footnotetext{
${ }^{17}$ As discussed in Section 4.6, the results of these tests are similar if I instead use OLS regression.
} 
interquartile range of each respective measure. ${ }^{18}$ In summary, the results reported in Table 4 provide support for my primary hypothesis.

\subsection{Cross-Sectional Analyses}

In this section, I investigate whether the results of my primary hypothesis tests vary predictably based on specific cross-sectional factors that are likely to influence the relation between targeted auditor switches and changes in company operating performance. I consider both across-market (i.e., industry- or geographic-level) factors and within-market (i.e., company-level) factors that are likely to affect this relation.

\subsubsection{Industry Concentration}

The first factor I consider is industry concentration. Ali et al. (2014) examine the association between industry concentration and corporate disclosure policy and find that companies in concentrated industries have more restrictive disclosure polices, presumably due to higher proprietary costs of disclosure. Ali et al. (2014) posit that proprietary costs are higher in concentrated industries because, in these industries, one company's information is relatively more valuable to the company's competitors and thus competitors are more likely to take advantage of any leakages (whether intentional or unintentional) of proprietary information. Motivated by the findings of Ali et al. (2014), I examine whether the association between targeted auditor switches and changes in operating performance varies with industry concentration. If the operational improvements associated with targeted switches are in fact attributable (at least in part) to spillovers of proprietary information via the auditor, then I expect that the improvements in operating performance will be more pronounced as industry concentration increases.

To test this prediction, I follow prior research (e.g., Hutton, Lee, and Shu 2012; Ali et al. ${ }^{18}$ These estimates are calculated as follows for operating income growth (operating cash flow growth): coefficient
estimate of $0.0174(0.0162)$ reported in Table 4 divided by interquartile range of $0.090(0.101)$ derived from Table 2 . 
2014; Amiram, Kalay, and Sadka 2017) and use the Herfindahl-Hirschman index to proxy for industry concentration. Specifically, I define industry concentration by year as the sum of the squares of market share (based on total revenues) for each company in a two-digit SIC industry (IndConc). Then, I re-estimate both specifications of Equation (1) after including IndConct ${ }_{t}$ as an additional independent variable, along with the interaction of TargetSwitch $t$ and IndConct. As outlined above, I expect a positive coefficient on the interaction of TargetSwitch $t$ and IndConct. The results of these tests are presented in Columns (1) and (2) of Table 5. For brevity, in each cross-sectional test I only report the results for the variables of interest. Consistent with my prediction, the coefficient estimate on TargetSwitch $_{t} *$ IndConct $_{t}$ is positive and significant in each estimation ( $p<0.05$ in Column $1 ; \mathrm{p}<0.01$ in Column 2). These results reveal that the association between changes in operating performance and targeted auditor switches is increasing in industry concentration, consistent with targeted switches resulting in greater operational benefits for companies in industries with relatively higher proprietary costs of disclosure.

\subsubsection{Enforceability of Non-Compete Agreements}

The second factor I consider is the strength of non-compete agreement enforcement. As an alternative to hiring a rival company's former auditor, companies can benefit from information spillovers through hiring individuals currently (or formerly) employed by a market competitor. Companies often use non-compete agreements to protect themselves from the transfer of proprietary information to a competitor through a former employee (Davis, Reicin, and Warren 2015). Prior research also shows that the strength of the enforceability of these non-compete agreements (which varies across states) affects the likelihood of this form of information spillover. Marx, Strumsky, and Fleming (2009) and Garmaise (2011) find that employee movement between rival companies is restricted in states with stronger non-compete enforcement, thus leading to less 
information spillover through this channel (Belenzon and Schankerman 2013). More directly relevant to my setting, Aobdia (2015) provides evidence that rival companies are less likely to share an auditor when headquartered in states with stronger non-compete enforcement, consistent with perceived auditor sharing costs being higher when employee movement is restricted. Accordingly, I expect that the positive association between targeted switches and changes in operating performance will be more pronounced for companies headquartered in states with relatively stronger enforcement of non-compete agreements given the limited ability of these companies to benefit from information spillovers through hiring a competitor's employees.

To test this prediction, I use a state-by-state index of non-compete enforceability formulated by Bishara (2011) and subsequently evaluated by Barnett and Sichelman (2020). Bishara (2011) systematically reviews both case law and state legislation to assess the relative strength of non-compete enforcement across states at two points in time (1991 and 2009). Bishara (2011) then ranks each of the fifty states and the District of Columbia from 1 (strongest enforcement) to 51 (weakest enforcement) at each point in time. Using these rankings, I define an indicator variable (Enforce) equal to one for audit engagements that occur in state-years in the top half of Bishara's (2011) rankings (i.e., state-years with relatively strong non-compete enforcement). For years prior to 2009 I use the 1991 rankings to define Enforce, and for years 2009 and after I use the 2009 rankings. Then, I re-estimate both specifications of Equation (1) after including Enforce $t_{t}$ as an additional independent variable, along with the interaction of

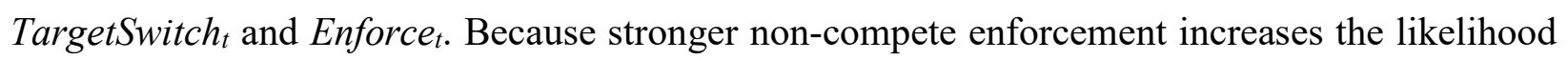
that companies will seek information spillover via the auditor, I expect a positive coefficient on

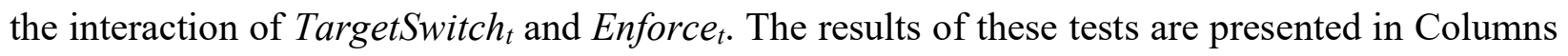
(3) and (4) of Table 5. Consistent with my prediction, the coefficient estimate on TargetSwitch $_{t}$ * 
Enforce $_{t}$ is positive and significant in each estimation ( $\mathrm{p}<0.05$ in both Columns), suggesting that the operational benefits associated with targeted auditor switches are greater in markets where non-compete enforcement is stronger. ${ }^{19}$

\subsubsection{Auditor Liability Exposure}

The third factor I consider is auditor liability exposure. Prior work documents that auditors are sensitive to litigation risk and consider their potential liability exposure when making client acceptance decisions (Laux and Newman 2010; Anantharaman et al. 2016; Honigsberg et al. 2019). In addition, auditors are likely to be relatively more sensitive to litigation risk in instances where a prospective client is a close competitor of a previous client. This is because, even absent any intent to disclose proprietary client information, the probability that an auditor faces litigation related to the disclosure of proprietary information is relatively higher in cases where the auditor successively engages with two or more local market competitors (Cashell and Fuerman 1995; McAllister and Cripe 2008). These litigation concerns are substantive given that auditors have historically faced legal actions related to the transfer of sensitive client information. For example, Grant Thornton was found liable for breach of confidentiality after sharing information related to the operations of one client to its other clients (Werner 2009). The precedent from this case (and several other similar cases) provides a strong incentive for auditors to avoid any actual or perceived leakages of information across clients in the face of more severe liability exposure (Aobdia 2015). Accordingly, I expect that the positive relation between changes in operating performance and targeted auditor switches will be reduced in markets where auditor liability exposure is relatively greater.

\footnotetext{
${ }^{19}$ My inferences are unchanged if I define Enforce using the actual index ranking (1 to 51) instead of dichotomizing at the median ranking, suggesting that the association between targeted switches and changes in operating performance is increasing across the distribution of the strength of non-compete agreement enforcement.
} 
To test this, I use the state-level liability-sharing index from Gaver, Paterson, and Pacini (2012) and Anantharaman et al. (2016) to define an indicator variable (HighLiab) equal to one for audit engagements that occur in state-years with the most stringent form of third-party legal liability (i.e., full joint-and-several liability). ${ }^{20}$ Then, I re-estimate both specifications of Equation (1) after including HighLiab as $_{t}$ an additional independent variable, along with the interaction of TargetSwitch $_{t}$ and HighLiab. Following Anantharaman et al. (2016), I limit the sample for this analysis to observations in 2009 and earlier since the state-level liability index is only updated through $2009 .{ }^{21}$ If greater liability exposure reduces the likelihood of auditor information spillover,

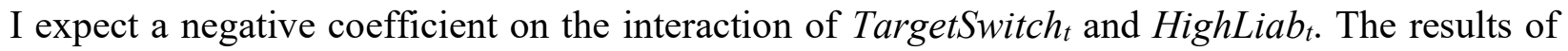
these tests are presented in Columns (5) and (6) of Table 5. Consistent with my prediction, the coefficient estimate on TargetSwitch $_{t} *$ HighLiab $_{t}$ is negative and significant in each estimation (p $<0.01$ in Column 5; $<<0.10$ in Column 6). These results reveal that the operational benefits of targeted auditor switches are reduced in markets where auditors face the possibility of more severe legal liability, consistent with relatively less auditor information spillover occurring in these markets.

\subsubsection{Inventory Intensity}

The fourth and final cross-sectional factor I consider is the extent of a company's assets

\footnotetext{
${ }^{20}$ This index is created based on the liability-sharing rules applied in each state across time. The index is developed from state-level summaries of joint-and-several liability reform by the American Tort Reform Association (2014). Prior work documents that third-party liability standards affect overall auditor litigation risk (e.g., Linville (2011) finds that auditors in states with more stringent third-party liability pay higher malpractice insurance premiums). The index assigns a value of 0 to state-years that follow a proportionate liability standard (least stringent form of thirdparty liability), 0.5 to state-years that follow a modified joint-and-several liability standard (moderately stringent form of third-party liability), and 1 to state-years that follow a full joint-and-several liability standard (most stringent form of third-party liability). If I define HighLiab using the actual index ranking $(0,0.5$, or 1$)$ instead of dichotomizing, the result holds for the test of changes in operating income, but the negative coefficient on the interaction of interest is no longer significant at conventional levels for the test of changes in operating cash flows $(p=0.273)$.

${ }^{21}$ If I include observations post-2009, the result holds for the test of changes in operating income, but the negative coefficient on the interaction of interest is no longer significant at conventional levels for the test of changes in operating cash flows $(p=0.159)$. However, I hesitate to extrapolate the index beyond 2009 given the significant changes in auditor liability laws over the past decade (Anantharaman et al. 2016; Honigsberg et al. 2019).
} 
that are made up of inventory (i.e., inventory intensity). Auditors learn about clients' inventory management systems through internal control audit procedures and other audit procedures (PCAOB 2010b; Bhattacharjee et al. 2012; Feng et al. 2015). Accordingly, I posit that one likely mechanism for spillovers of operational information is through auditors' knowledge of clients' inventory management systems. This proposed link is further supported by Feng et al. (2015), who provide evidence that internal controls (specifically controls over inventory management) have a significant impact on firm operations. Inventory management is a critical component of a company's operational strategy, and weaknesses in inventory controls are likely to lead to higher inventory-related costs (Feng et al. 2015). In addition, auditors often communicate about operational issues identified in clients' inventory management processes, as well as provide recommendations to address such issues, through informal discussions with management and through management letter comments (Moreno and Bhattacharjee 2003; Metzler 2005; Aronson LLC 2014). Given the evidence outlined above suggesting that the operational value of an auditor's knowledge is likely to be relatively greater for inventory-related issues, I expect that the operational improvements associated with targeted auditor switches will be more pronounced for inventory-intensive companies.

To test this, I follow prior research and generate a measure of inventory intensity for each company-year in the sample. Specifically, I define InvIntens as the ratio of total inventories (including the LIFO reserve) to total assets (Mauler 2019). Then, I re-estimate both specifications of Equation (1) after including InvIntens $s_{t}$ as an additional independent variable, along with the interaction of TargetSwitch $t$ and InvIntenst. As outlined above, I predict that the association between targeted auditor switches and changes in operating performance will be increasing in company-level inventory intensity, and thus I expect a positive coefficient on the interaction of 


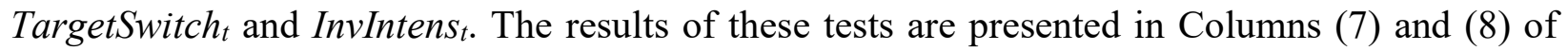
Table 5. Consistent with my prediction, the coefficient estimate on TargetSwitch ${ }_{t}^{*}$ InvIntens $_{t}$ is positive and significant in each estimation $\left(\mathrm{p}<0.05\right.$ in Column 7; $\mathrm{p}<0.01$ in Column 8). ${ }^{22}$

\subsection{Test of Auditor-Client Realignments}

I use this section to investigate whether there is systematic movement (i.e., auditor-client realignments) in local audit markets consistent with a recognition of the value of auditors' operational knowledge. If companies recognize the potential operational value of switching to an auditor formerly engaged with a local market competitor, then I expect that these types of switches will occur with abnormal frequency. In other words, I expect that companies will be more likely to switch to an auditor formerly engaged with a local market competitor if there is an auditor change within the local market in the preceding period. I expect this type of systematic movement following a prior-period competitor auditor switch because, in these instances, companies have the opportunity to engage an auditor with extensive knowledge of a local market competitor without bearing any auditor sharing costs. Despite this prediction, it is possible that the costs of switching auditors (Skinner and Srinivasan 2012) outweigh the expected value of any benefits of making this type of auditor change. If this is true on average, then I would not expect to observe the predicted systematic movement in the affected markets.

To test my prediction, I begin by defining MarketSwitch as an indicator variable equal to one if a local market competitor company switches auditors, and zero otherwise. I then use multinomial logistic regression (Landsman et al. 2009) to simultaneously test whether, following

\footnotetext{
${ }^{22}$ If I include each of the cross-sectional variables described in Section 4.3 (IndConct, Enforce, , HighLiab ${ }_{t}$, and Invintens $s_{t}$ ) as additional explanatory variables in the primary estimations of Equation (1), my inferences are unchanged. In addition, my inferences from each of the cross-sectional tests discussed in this section are unchanged if I interact the cross-sectional variable of interest with each of the other explanatory variables (i.e., the results are robust to a fully-interacted specification).
} 


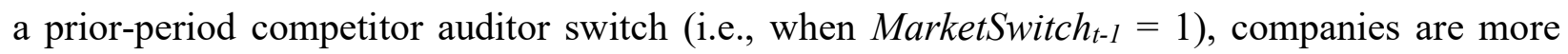
likely in period $t$ to switch to an auditor formerly engaged with a local market competitor versus switch to an auditor not formerly engaged with a local market competitor, relative to the choice to retain their auditor (the reference group). I include the same set of control variables from Equation (1), along with three additional variables (Expert, Mismatch, and Tenure) commonly employed in the auditor switching literature (e.g., Landsman et al. 2009). ${ }^{23}$ These three variables are excluded from Equation (1) because they are potential outcomes of an auditor switch and thus are "bad controls" for my primary hypothesis tests (Angrist and Pischke 2015; Swanquist and Whited 2018). ${ }^{24}$ As outlined above, I predict that companies will be more likely to switch to an auditor formerly engaged with a competitor following a prior-period competitor auditor switch (i.e., I expect a positive association between MarketSwitch t- $_{1}$ and switches to a competitor's former auditor). I make no prediction for the relation between MarketSwitch t-l $_{1}$ and switches to auditors not formerly engaged with a competitor.

The results of this estimation are presented in Table 6 . As noted above, the reference group consists of companies that do not switch auditors in period $t$. Column (1) reports the results for companies that switch in period $t$ to an auditor that was engaged with a local market competitor in period $t-1$, and Column (2) reports the results for companies that switch to all other auditors in period $t$. Consistent with my prediction, the coefficient on MarketSwitch $_{t-1}$ is positive and significant in Column (1) $(\mathrm{p}<0.01)$. In contrast, the coefficient on MarketSwitch M $_{t-1}$ in Column (2) is negative and significant. Taken together, these results suggest that companies are more likely to switch auditors following a prior-period competitor auditor switch, but only when the subsequently

\footnotetext{
${ }^{23}$ Expert indicates whether the auditor is an industry expert, Mismatch indicates whether the auditor and client are "mismatched" following the methodology in Shu (2000), and Tenure represents auditor tenure. All three variables are formally defined in Appendix B.

${ }^{24}$ Nonetheless, inferences throughout the paper are unchanged if I include these three variables in each test.
} 
selected auditor was engaged with a competitor company in the preceding period. More broadly, these results provide evidence of systematic movement within local audit markets consistent with a recognition of the potential operational value of auditor information spillovers.

\subsection{Audit Pricing and Auditor Quality}

\subsubsection{Targeted Auditor Switches and Audit Pricing}

To provide further insights into targeted auditor switches, I next examine the relation between these types of switches and audit pricing. Prior work documents that companies that switch auditors often receive an initial audit fee discount from the incoming auditor (DeAngelo 1981; Craswell and Francis 1999; Doogar, Sivadasan, and Solomon 2015). ${ }^{25}$ However, given that the switches I define as targeted are associated with subsequent improvements in operating performance, I expect that the agreed-upon price of the audit will reflect the value of these improvements and thus targeted switches will be associated with a higher initial audit price relative to non-targeted switches. Consistent with this, analytical work predicts that the price of an audit should reflect the value of the auditor's informational capital (Elitzur and Falk 1996; Chan 1999). On the other hand, one of the necessary conditions of a targeted switch is that the targeted auditor loses at least one local market client in the preceding period. This condition could result in excess capacity for the auditor, which in turn could lead to a reduction in audit price for these types of engagements.

I test the relation between targeted auditor switches and audit pricing by performing comparisons based on the abnormal audit fee paid to the auditor for each observation in the sample. To calculate the abnormal audit fee, I regress the natural logarithm of audit fees paid to the

\footnotetext{
${ }^{25}$ Barua, Lennox, and Raghunandan (2020) suggest that the inferences from prior work that examines audit fee discounting are potentially subject to measurement bias because interim audit procedures are often performed by both the predecessor and successor auditors but only the successor's fee needs to be disclosed.
} 
company's auditor in year $t$ on the same set of control variables from Equation (1). ${ }^{26}$ For each company-year observation, I then define the residual from this regression estimation as the abnormal audit fee $\left(\right.$ AbnFee $\left._{t}\right)$ (Doogar et al. 2015). I then compare the mean values of $A b n F e e_{t}$ across companies that make targeted switches $\left(\right.$ Target $\left._{\text {Switch }}=1\right)$ and three comparison groups, including all other companies in the sample (TargetSwitch $=0)$, companies that do not switch auditors $\left(\right.$ Switch $\left._{t}=0\right)$, and companies that make non-targeted switches $\left(\right.$ OtherSwitch $\left.{ }_{t}=1\right){ }^{27}$

The results of these comparisons are reported in Table 7. As shown, companies that make a targeted auditor switch on average pay a considerable abnormal audit fee premium (12.3 percent) in the year of the switch. In contrast, companies that do not switch auditors have an average abnormal audit fee that is close to zero ( 0.5 percent), and companies that make a non-targeted auditor switch on average receive a substantial fee discount (12.2 percent). Two-sided t-tests of the differences across these groups are reported in the right-side columns of the table. As shown, each of the across-group differences is statistically significant. In summary, these results suggest that companies that make targeted auditor switches pay a significant audit fee premium relative to both companies that do not switch auditors and companies that make non-targeted switches, consistent with the value of targeted auditors' knowledge being impounded into audit price.

\subsubsection{Targeted Auditor Switches and Auditor Quality}

While the results of the audit pricing analysis are consistent with clients paying a premium to account for the value of auditors' informational capital, a plausible alternative explanation is that targeted auditor switches and the corresponding audit fee premium are attributable to

\footnotetext{
${ }^{26}$ Inferences are unchanged for both the audit pricing analysis discussed here and the auditor quality analysis (discussed in the following sub-section) if I include Expert $t_{t}$ Mismatch $_{t}$, and Tenure $t_{t}$ as additional explanatory variables. The results also hold if I include MSA fixed effects to account for any time-invariant differences in audit pricing or auditor quality across markets.

${ }^{27}$ Switch is defined as an indicator variable equal to one if the company switches auditors, and zero otherwise (i.e., Switch $=1$ if TargetSwitch $=1$ or OtherSwitch $=1$ ).
} 
companies' desire for higher auditor quality. In other words, it is possible that companies that make targeted switches systematically select and pay a premium for higher-quality auditors. To address this alternative explanation, I examine the preceding average audit quality provided by targeted auditors relative to other auditors in the sample. I use an audit office's prior-period misstatement rate - the number of clients in the office with a misstatement in year $t-1$ divided by the total number of clients in the same audit office in year $t-1$ (AuditorMistRate A $_{\text {- }}$ - to proxy for

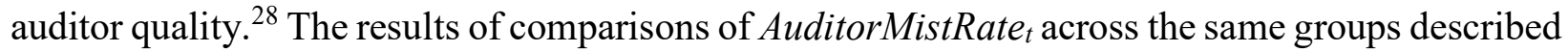
above are presented in Panel A of Table 8. As shown, targeted auditors $\left(\right.$ TargetSwitch $\left._{t}=1\right)$ are lower-quality auditors on average relative to all other auditors in the sample $\left(\right.$ TargetSwitch $\left._{t}=0\right)$, auditors engaged by companies that do not switch auditors $(S w i t c h=0)$, and auditors engaged by companies making non-targeted switches $\left(\right.$ OtherSwitch $\left.h_{t}=1\right)$, evidenced by a significantly higher average prior-period misstatement rate. These results do not support the alternative explanation that targeted auditor switches are associated with the desire for higher auditor quality.

To ensure that the differences in auditor quality across these groups are not attributable to other observable client and/or auditor characteristics, I also perform a multiple regression analysis. Specifically, I regress AuditorMistRate on TargetSwitch $_{t}$, OtherSwitch, and the same set of control variables from Equation (1). ${ }^{29}$ The results of this estimation are presented in Panel B of Table 8. Consistent with the evidence from Panel A, the coefficient on TargetSwitch $t$ is positive and significant $(\mathrm{p}<0.05)$ and is significantly different than the coefficient on OtherSwitch ${ }_{t}$, suggesting that companies making targeted switches on average subsequently select auditors with higher

\footnotetext{
28 In the tabulated analyses I use all misstatements (i.e., both "Big R" and "Little r" misstatements) to calculate AuditorMistRate . However, in untabulated analyses I use only "Big R" misstatements and find similar results. Also, the sample for the auditor quality analyses is slightly smaller than the primary sample due to the loss of 426 observations with insufficient data necessary to calculate AuditorMistRate $_{t}$.

${ }^{29}$ Because the calculation of the abnormal audit fee discussed in the preceding sub-section already accounts for the control variables from Equation (1), a multiple regression test is not necessary for the audit pricing analysis.
} 
preceding rates of audit failure relative to both companies that do not switch auditors and companies that make non-targeted switches.

\subsection{Robustness Tests}

\subsubsection{Decile Ranks of Changes in Operating Performance}

To ensure that the results of the primary estimations of Equation (1) are not a function of the distributional properties of the dependent variables (i.e., to ensure that the results hold across the distribution of each variable), I re-estimate both specifications of Equation (1) after decileranking each dependent variable. Specifically, I decile-rank changes in operating income and changes in operating cash flows to create two new variables that are scaled such that the highest (lowest) decile is equal to one (zero). The results of the tests using the decile-ranked dependent variables (untabulated) are consistent with the primary results.

\subsubsection{Inclusion of MSA Fixed Effects}

Next, to ensure that the results of the primary estimations of Equation (1) are not attributable to certain time-invariant characteristics of the local markets with targeted switches, I re-estimate each of the specifications of Equation (1) after including MSA fixed effects. The results of these tests (untabulated) are consistent with the primary results and provide comfort that timeinvariant local market characteristics do not explain the relation between targeted switches and changes in operating performance. The results are also robust to the inclusion of MSA-year fixed effects, suggesting that other time-variant characteristics of local markets do not explain the relation of interest.

\subsubsection{OLS Regression}

I use robust regression as the primary method to estimate Equation (1), consistent with the recommendations from prior research for samples that involve a small number of treatment 
observations (Ryan et al. 2016; Kelly et al. 2017; Leone et al. 2019). However, for robustness, I re-estimate both specifications of Equation (1) using OLS regression instead of robust regression. The results of these tests (untabulated) are consistent with the primary results and provide additional comfort that my inferences are not contingent on my research design decisions.

\subsubsection{Tests for Equality of Distribution Functions}

As a final robustness test, I compare the distributions of changes in operating performance for targeted switches to the distributions for each of the main comparison groups (i.e., non-switches and other switches). More specifically, I statistically assess whether these distributions are different from one another using the two-sample Kolmogorov-Smirnov test. The KolmogorovSmirnov test is a non-parametric test of whether two independent samples are from populations with the same distribution (Busse and Green 2002). This test is one of the most preferred nonparametric techniques because it does not depend on the underlying population distributions and because it is reliable for small sample sizes (Chakravarti, Laha, and Roy 1967). Untabulated Kolmogorov-Smirnov tests reveal that the distributions of both $\triangle O P I n c_{t+2, t}$ and $\triangle O p C F_{t+2, t}$ for targeted switches are statistically different than those for each comparison group (targeted switches vs. non-switches: $\mathrm{p}<0.01$ for both measures; targeted switches vs. other switches: $\mathrm{p}<0.01$ for $\Delta O \operatorname{Pnc}_{t+2, t}$ and $\mathrm{p}<0.05$ for $\left.\triangle O p C F_{t+2, t}\right)$.

\section{Conclusion}

Despite auditors' codified obligation to protect sensitive client information, there is extant evidence suggesting that companies are reluctant to share an auditor with a competitor company over concerns of proprietary information spillovers (Tierney 1989; Berton and Niebuhr 1990; Aobdia 2015; Bills et al. 2020; Kang et al. 2020). In this study, I attempt to provide evidence as to whether companies' concerns over auditor information spillovers are justified. To do so, I examine 
whether companies realize operational benefits from making "targeted auditor switches" (i.e., engaging a new auditor recently dismissed by a competitor company). I find that companies that make these types of switches realize greater subsequent improvements in operating performance relative to both companies that do not switch auditors and companies that make non-targeted switches, and I document that the association between targeted auditor switches and improvements in operating performance varies predictably with several across- and within-market factors. In addition, I document systematic movement in local audit markets consistent with a recognition of the value of auditors' operational knowledge. Finally, I find that companies that make targeted switches pay a significant audit fee premium to the incoming auditor and that this premium does not appear to be attributable to these companies hiring higher-quality auditors.

This study provides evidence suggesting that proprietary information is transferred (either intentionally or unintentionally) across companies via external auditors and that auditor information spillovers are associated with significant operational benefits for the companies to which the information is likely being transferred. Furthermore, the collective evidence suggests that the value of an audit (auditor) is associated with the auditor's informational capital and extends beyond that which is traditionally considered by investors and other capital market participants (Healy and Palepu 2001; DeFond and Zhang 2014). Given that auditors accumulate more information about their clients than arguably any other external party (SEC 2000; KPMG 2014), my findings should be of interest to wide range of stakeholders, including managers, board members, investors, and regulators. Finally, although I do not examine concurrent auditor sharing between competitor companies, the results of my study suggest that companies' concerns over auditor sharing are likely based on real information spillover costs and that these costs are potentially relevant to the auditor selection process. 


\section{REFERENCES}

Ali, A., S. Klasa, and E. Yeung. 2014. Industry concentration and corporate disclosure policy. Journal of Accounting and Economics 58 (2-3): 240-264.

American Institute of Certified Public Accountants (AICPA). 2013. Code of professional conduct and bylaws. New York, June 1.

American Tort Reform Association (ATRA). 2014. Joint and several liability rule reform. Available at: http://www.atra.org/issues/joint-and-several-liability-rule-reform.

Amiram, D., A. Kalay, and G. Sadka. 2017. Industry characteristics, risk premiums, and debt pricing. The Accounting Review 92 (1): 1-27.

Anand, K. S., and M. Goyal. 2009. Strategic information management under leakage in a supply chain. Management Science 55 (3): 438-452.

Anantharaman, D., J. A. Pittman, and N. Wans. 2016. State liability regimes within the United States and auditor reporting. The Accounting Review 91 (6): 1545-1575.

Angrist, J. D., and J. S. Pischke. 2015. Mastering 'metrics: The path from cause to effect. Princeton University Press.

Aobdia, D. 2015. Proprietary information spillovers and supplier choice: Evidence from auditors. Review of Accounting Studies 20 (4): 1504-1539.

Aronson LLC. 2014. Avoiding management letter comments - inventory. Available at: https://aronsonllc.com/avoiding-management-letter-comments/.

Barber, B. M., and J. D. Lyon. 1996. Detecting abnormal operating performance: The empirical power and specification of test statistics. Journal of Financial Economics 41 (3): 359-399.

Barnett, J. M., and T. Sichelman. 2020. The case for noncompetes. University of Chicago Law Review 87 (4): 953-1049.

Barua, A., C. Lennox, and A. Raghunandan. 2020. Are audit fees discounted in initial year audit engagements? Journal of Accounting and Economics 69 (2-3): 101282.

Belenzon, S., and M. Schankerman. 2013. Spreading the word: Geography, policy, and knowledge spillovers. Review of Economics and Statistics 95 (3): 884-903.

Berton, L., and R. G. Niebuhr. 1990. Ernst \& Young is forced to drop PepsiCo as a client. The Wall Street Journal, February 26.

Bhattacharjee, S., K. K. Moreno, and T. Riley. 2012. The interplay of interpersonal affect and source reliability on auditors' inventory judgments. Contemporary Accounting Research 29 (4): 1087-1108.

Bills, K. L., M. Cobabe, J. Pittman, and S. E. Stein. 2020. To share or not to share: The importance of peer firm similarity to auditor choice. Accounting, Organizations and Society 83: 101115.

Bishara, N. D. 2011. Fifty ways to leave your employer: Relative enforcement of covenants not to compete, trends, and implications for employee mobility policy. University of Pennsylvania Journal of Business Law 13 (3): 751-796. 
Blackwell, D. W., D. M. Dudney, and K. A. Farrell. 2007. Changes in CEO compensation structure and the impact on firm performance following CEO turnover. Review of Quantitative Finance and Accounting 29 (3): 315-338.

Busse, J. A., and T. C. Green. 2002. Market efficiency in real time. Journal of Financial Economics 65 (3): 415-437.

Cahan, S. F., J. M. Godfrey, J. Hamilton, and D. C. Jeter. 2008. Auditor specialization, auditor dominance, and audit fees: The role of investment opportunities. The Accounting Review 83 (6): 1393-1423.

Cai, Y., Y. Kim, J. C. Park, and H. D. White. 2016. Common auditors in M\&A transactions. Journal of Accounting and Economics 61 (1): 77-99.

Cashell, J. D., and R. D. Fuerman. 1995. The CPA's responsibility for client information. The CPA Journal 65 (9): 54-57.

Chakravarti, I. M., R. G. Laha, and J. Roy. 1967. Handbook of methods of applied statistics (Volume 1). John Wiley and Sons.

Chan, D. K. 1999. "Low-balling” and efficiency in a two-period specialization model of auditing competition. Contemporary Accounting Research 16 (4): 609-642.

Christensen, B. E., A. J. Olson, and T. C. Omer. 2015. The role of audit firm expertise and knowledge spillover in mitigating earnings management through the tax accounts. The Journal of the American Taxation Association 37 (1): 3-36.

Chu, L., D. A. Simunic, M. Ye, and P. Zhang. 2018. Transaction costs and competition among audit firms in local markets. Journal of Accounting and Economics 65 (1): 129-147.

Core, J. E., and D. F. Larcker. 2002. Performance consequences of mandatory increases in executive stock ownership. Journal of Financial Economics 64 (3): 317-340.

Cowan, A. L. 1990. Ernst drops Pepsi for Coke as auditor. The New York Times, February 24.

Cowle, E. N., T. J. Kleppe, J. R. Moon, and J. E. Shipman. 2019. Client consulting opportunities and the reemergence of Big 4 consulting practices: Implications for the audit market. Working paper, University of Arkansas and Georgia Institute of Technology.

Craswell, A. T., and J. R. Francis. 1999. Pricing initial audit engagements: A test of competing theories. The Accounting Review 74 (2): 201-216.

Davis, A., E. D. Reicin, and M. Warren. 2015. Developing trends in non-compete agreements and other restrictive covenants. ABA Journal of Labor \& Employment Law 30 (2): 255-272.

DeAngelo, L. E. 1981. Auditor independence, "low balling”, and disclosure regulation. Journal of Accounting and Economics 3 (2): 113-127.

Dechow, P. M., R. G. Sloan, and A. P. Sweeney. 1995. Detecting earnings management. The Accounting Review 70 (2): 193-225.

DeFond, M., and J. Zhang. 2014. A review of archival auditing research. Journal of Accounting and Economics 58 (2-3): 275-326.

Degeorge, F., and R. Zeckhauser. 1993. The reverse LBO decision and firm performance: Theory and evidence. The Journal of Finance 48 (4): 1323-1348. 
Dhaliwal, D. S., P. T. Lamoreaux, L. P. Litov, and J. B. Neyland. 2016. Shared auditors in mergers and acquisitions. Journal of Accounting and Economics 61 (1): 49-76.

Doogar, R., P. Sivadasan, and I. Solomon. 2015. Audit fee residuals: Costs or rents? Review of Accounting Studies 20 (4): 1247-1286.

Dye, R. A. 1986. Proprietary and nonproprietary disclosures. Journal of Business 59 (2): 331-366.

Eilifsen, A., W. R. Knechel, and P. Wallage. 2001. Application of the business risk audit model: A field study. Accounting Horizons 15 (3): 193-207.

Elitzur, R. R., and H. Falk. 1996. Auctions for audit services and low-balling. Auditing: A Journal of Practice and Theory 15: 41-59.

Feng, M., C. Li, S. E. McVay, and H. Skaife. 2015. Does ineffective internal control over financial reporting affect a firm's operations? Evidence from firms' inventory management. The Accounting Review 90 (2): 529-557.

Fontaine, R., S. B. Letaifa, and D. Herda. 2013. An interview study to understand the reasons clients change audit firms and the client's perceived value of the audit service. Current Issues in Auditing 7 (1): A1-A14.

Francis, J. R., K. Reichelt, and D. Wang. 2005. The pricing of national and city-specific reputations for industry expertise in the U.S. audit market. The Accounting Review 80 (1): 113-136.

Garmaise, M. J. 2011. Ties that truly bind: Noncompetition agreements, executive compensation, and firm investment. The Journal of Law, Economics, and Organization 27 (2): 376-425.

Gaver, J. J., J. S. Paterson, and C. J. Pacini. 2012. The influence of auditor state-level legal liability on conservative financial reporting in the property-casualty insurance industry. Auditing: A Journal of Practice and Theory 31 (3): 95-124.

Grindley, P., D. C. Mowery, and B. Silverman. 1994. SEMATECH and collaborative research: Lessons in the design of high-technology consortia. Journal of Policy Analysis and Management 13 (4): 723-758.

Hay, D. C., W. R. Knechel, and N. Wong. 2006. Audit fees: A meta-analysis of the effect of supply and demand attributes. Contemporary Accounting Research 23 (1): 141-191.

Healy, P. M., and K. G. Palepu. 2001. Information asymmetry, corporate disclosure, and the capital markets: A review of the empirical disclosure literature. Journal of Accounting and Economics 31 (1-3): 405-440.

Honigsberg, C., S. Rajgopal, and S. Srinivasan. 2019. The changing landscape of auditor liability. Journal of Law and Economics (Forthcoming).

Hutton, A. P., L. F. Lee, and S. Z. Shu. 2012. Do managers always know better? The relative accuracy of management and analyst forecasts. Journal of Accounting Research 50 (5): 1217-1244.

Kang, J. K., C. Lennox, and V. Pandey. 2020. Client concerns about information spillovers from sharing audit partners. Working paper, University of Southern California.

Kaplan, S. 1989. The effects of management buyouts on operating performance and value. Journal of Financial Economics 24 (2): 217-254. 
Kelly, K., A. Presslee, and R. A. Webb. 2017. The effects of tangible rewards versus cash rewards in consecutive sales tournaments: A field experiment. The Accounting Review 92 (6): 165185.

Kim, K. A., P. Kitsabunnarat, and J. R. Nofsinger. 2004. Ownership and operating performance in an emerging market: Evidence from Thai IPO firms. Journal of Corporate Finance 10 (3): 355-381.

Kong, G., S. Rajagopalan, and H. Zhang. 2013. Revenue sharing and information leakage in a supply chain. Management Science 59 (3): 556-572.

KPMG. 2014. Value of audit: Shaping the future of corporate reporting. Available at: https://home.kpmg/content/dam/kpmg/pdf/2015/12/value-of-audit-shaping-the-future-ofcorporate-rep.pdf.

Landsman, W. R., K. K. Nelson, and B. R. Rountree. 2009. Auditor switches in the pre- and postEnron eras: Risk or realignment? The Accounting Review 84 (2): 531-558.

Laux, V., and D. P. Newman. 2010. Auditor liability and client acceptance decisions. The Accounting Review 85 (1): 261-285.

Leone, A. J., M. Minutti-Meza, and C. E. Wasley. 2019. Influential observations and inference in accounting research. The Accounting Review 94 (6): 337-364.

Li, S., and B. Lin. 2006. Accessing information sharing and information quality in supply chain management. Decision Support Systems 42 (3): 1641-1656.

Lim, C., and H. Tan. 2008. Non-audit service fees and audit quality: The impact of auditor specialization. Journal of Accounting Research 46 (1): 199-246.

Linville, M. 2011. The effects of state tort provisions and perceptions of litigation risk on malpractice insurance. Journal of Applied Business Research 17 (3): 61-69.

Lisic, L. L., L. A. Myers, R. Pawlewicz, and T. A. Seidel. 2019. Do accounting firm consulting revenues affect audit quality? Evidence from the pre- and post-SOX eras. Contemporary Accounting Research 36 (2): 1028-1054.

Marx, M., D. Strumsky, and L. Fleming. 2009. Mobility, skills, and the Michigan non-compete experiment. Management Science 55 (6): 875-889.

Mauler, L. M. 2019. The effect of analysts' disaggregated forecasts on investors and managers: Evidence using pre-tax forecasts. The Accounting Review 94 (3): 279-302.

McAllister, B., and B. Cripe. 2008. Improper release of proprietary information. The CPA Journal 78 (3): $52-55$.

McDonald, D. 2013. The firm: The story of McKinsey and its secret influence on American business. Simon and Schuster.

Metzler, J. C. 2005. How the AICPA helps members serve small business. Journal of Accountancy 199 (3): 26-28.

Mobbs, S. 2013. CEOs under fire: The effects of competition from inside directors on forced CEO turnover and CEO compensation. Journal of Financial and Quantitative Analysis 48 (3): 669-698. 
Moreno, K., and S. Bhattacharjee. 2003. The impact of pressure from potential client business opportunities on the judgments of auditors across professional ranks. Auditing: A Journal of Practice and Theory 22 (1): 13-28.

Numan, W., and M. Willekens. 2012. An empirical test of spatial competition in the audit market. Journal of Accounting and Economics 53 (1-2): 450-465.

Public Company Accounting Oversight Board (PCAOB). 2007. Auditing Standard 3101: The auditor's report on an audit of financial statements when the auditor expresses an unqualified opinion. Washington, D.C., June 1.

Public Company Accounting Oversight Board (PCAOB). 2010a. Auditing Standard 2101: Audit planning. Washington, D.C., August 5.

Public Company Accounting Oversight Board (PCAOB). 2010b. Auditing Standard 2110: Identifying and assessing risks of material misstatement. Washington, D.C., August 5.

Public Company Accounting Oversight Board (PCAOB). 2018. PCAOB transitions for the future. 2018 Deloitte / University of Kansas Auditing Symposium. Lawrence, KS, May 17.

Rapoport, M. 2013. An insider trader says friendship drove acts. The Wall Street Journal Europe, July 1.

Ryan, S. G., J. W. Tucker, and Y. Zhou. 2016. Securitization and insider trading. The Accounting Review 91 (2): 649-675.

Securities and Exchange Commission (SEC). 2000. Comment Letters of Deloitte \& Touche on the Proposed Revision of the SEC's Auditor Independence Requirements. Washington, D.C., September 25.

Sengupta, K., D. R. Heiser, and L. S. Cook. 2006. Manufacturing and service supply chain performance: A comparative analysis. Journal of Supply Chain Management 42 (4): 4-15.

Shu, S. Z. 2000. Auditor resignations: Clientele effects and legal liability. Journal of Accounting and Economics 29 (2): 173-205.

Skinner, D. J., and S. Srinivasan. 2012. Audit quality and auditor reputation: Evidence from Japan. The Accounting Review 87 (5): 1737-1765.

Swanquist, Q. T., and R. L. Whited. 2018. Out of control: The (over)use of controls in accounting research. Working paper, University of Alabama and North Carolina State University.

Tan, K. H., W. P. Wong, and L. Chung. 2016. Information and knowledge leakage in supply chain. Information Systems Frontiers 18 (3): 621-638.

Tierney, C. 1989. Accounting mergers make clients uneasy. The Record, July 9.

Wasley, C. E., and J. S. Wu. 2006. Why do managers voluntarily issue cash flow forecasts? Journal of Accounting Research 44 (2): 389-429.

Werner, C. A. 2009. Accountant confidentiality. The CPA Journal 79 (6): 62-67. 


\section{APPENDICES}

\section{Appendix A: AICPA Code of Professional Conduct Rule 301}

.01 Rule 301-Confidential client information. A member in public practice shall not disclose any confidential client information without the specific consent of the client.

This rule shall not be construed (1) to relieve a member of his or her professional obligations under rules 202 [ET section 202.01] and 203 [ET section 203.01], (2) to affect in any way the member's obligation to comply with a validly issued and enforceable subpoena or summons, or to prohibit a member's compliance with applicable laws and government regulations, (3) to prohibit review of a member's professional practice under AICPA or state CPA society or Board of Accountancy authorization, or (4) to preclude a member from initiating a complaint with, or responding to any inquiry made by, the professional ethics division or trial board of the Institute or a duly constituted investigative or disciplinary body of a state CPA society or Board of Accountancy.

Members of any of the bodies identified in (4) above and members involved with professional practice reviews identified in (3) above shall not use to their own advantage or disclose any member's confidential client information that comes to their attention in carrying out those activities. This prohibition shall not restrict members' exchange of information in connection with the investigative or disciplinary proceedings described in (4) above or the professional practice reviews described in (3) above. [As amended January 14, 1992.]

\section{Interpretations under Rule 301-Confidential Client Information \\ [.02] [301-1]-[Deleted] \\ [.03] [301-2]—[Deleted]}

.04 301-3 - Confidential information and the purchase, sale, or merger of a practice. Rule 301 [ET section 301.01] prohibits a member in public practice from disclosing any confidential client information without the specific consent of the client. The rule provides that it shall not be construed to prohibit the review of a member's professional practice under AICPA or state CPA society authorization.

For purposes of rule 301 [ET section 301.01], a review of a member's professional practice is hereby authorized to include a review in conjunction with a prospective purchase, sale, or merger of all or part of a member's practice. The member must take appropriate precautions (for example, through a written confidentiality agreement) so that the prospective purchaser does not disclose any information obtained in the course of the review, since such information is deemed to be confidential client information.

Members reviewing a practice in connection with a prospective purchase or merger shall not use to their advantage nor disclose any member's confidential client information that comes to their attention. [Effective February 28, 1990.] 


\section{Appendix B: Variable Definitions}

\begin{tabular}{|c|c|}
\hline Variable & Definition \\
\hline$\triangle O p C F$ & $\begin{array}{l}\text { Two-year change in the company's operating cash flows } \\
\text { scaled by average total assets. }\end{array}$ \\
\hline$\Delta O p \operatorname{Inc}$ & $\begin{array}{l}\text { Two-year change in the company's operating income, scaled } \\
\text { by average total assets. }\end{array}$ \\
\hline AbnFee & $\begin{array}{l}\text { The residual from the regression estimation of the natural } \\
\text { logarithm of audit fees paid to the company's auditor on the } \\
\text { same set of control variables from Equation (1). }\end{array}$ \\
\hline Age & $\begin{array}{l}\text { The difference between the current fiscal year and the first } \\
\text { fiscal year in which the company appears in Compustat. }\end{array}$ \\
\hline AuditorMistRate & $\begin{array}{l}\text { For a given audit office, defined as the number of clients with } \\
\text { a misstatement in the preceding period, divided by the total } \\
\text { number of clients in the same period. }\end{array}$ \\
\hline Cash & Cash divided by total assets. \\
\hline CEOChange & $\begin{array}{l}\text { An indicator variable equal to one if the company changes } \\
\text { CEOs, and zero otherwise. }\end{array}$ \\
\hline DiscAcc & $\begin{array}{l}\text { The absolute value of discretionary accruals, calculated } \\
\text { according to the Modified Jones Model (Dechow, Sloan, and } \\
\text { Sweeney 1995). }\end{array}$ \\
\hline Enforce & $\begin{array}{l}\text { An indicator variable equal to one if the audit engagement } \\
\text { occurs in a state-year in the top half of Bishara's (2011) state- } \\
\text { by-state index of non-compete agreement enforceability, and } \\
\text { zero otherwise. }\end{array}$ \\
\hline Expert & $\begin{array}{l}\text { An indicator variable equal to one if the ratio of the auditor's } \\
\text { number of clients in the industry to the auditor's total number } \\
\text { of clients is greater than the median ratio for all auditors in the } \\
\text { sample, and zero otherwise. }\end{array}$ \\
\hline GoingConcern & $\begin{array}{l}\text { An indicator variable equal to one if the company receives a } \\
\text { going concern audit opinion, and zero otherwise. }\end{array}$ \\
\hline Growth & $\begin{array}{l}\text { The year-over-year percentage change in the company's total } \\
\text { assets. }\end{array}$ \\
\hline HighLiab & $\begin{array}{l}\text { An indicator variable equal to one if the audit engagement } \\
\text { occurs in a state-year with full joint-and-several liability, and } \\
\text { zero otherwise (Gaver, Paterson, and Pacini 2012; } \\
\text { Anantharaman, Pittman, and Wans 2016). }\end{array}$ \\
\hline
\end{tabular}


IndConc

InvIntens

InvRec

Leverage

Loss

$M \& A$

MarketSwitch

Mismatch

ModOpinion

OtherSwitch

$R O A$

Size

Switch

TargetSwitch

Tenure
Calculated by year as the sum of the squares of market share (based on total revenues) for each company in a two-digit SIC industry.

The ratio of the company's total inventories (including the LIFO reserve) to total assets (Mauler 2019).

The sum of inventory and receivables divided by total assets.

Total debt divided by total assets.

An indicator variable equal to one if return on assets is less than zero, and zero otherwise.

An indicator variable equal to one if the company reports merger and/or acquisition activity, and zero otherwise.

An indicator variable equal to one if a local market competitor company switches auditors, and zero otherwise.

An indicator variable equal to one for mismatched auditorclient engagements defined following Shu (2000), and zero otherwise.

An indicator variable equal to one if the company's audit opinion is modified for anything other than a going concern, and zero otherwise.

An indicator variable equal to one if the company switches auditors and does not make a targeted switch (i.e., TargetSwitch $=0$ ), and zero otherwise.

Return on assets, defined as net income before extraordinary items divided by average total assets.

The natural logarithm of the company's total assets.

An indicator variable equal to one if the company switches auditors, and zero otherwise.

An indicator variable equal to one if the company switches auditors and the incoming auditor was dismissed by (or resigned from) one of the company's local market competitors in the preceding period, and zero otherwise.

The number of years audited by the incumbent auditor. 
Table 1: Sample Selection

Observations

Observations at the intersection of Compustat and Audit Analytics for fiscal years 2002

through 2016

94,781

Less:

Observations without necessary data to construct test variables

Observations without necessary data to construct control variables

Observations in MSA-industries with less than three auditor-client pairs

$(9,081)$

Total observations meeting full sample criteria

27,644

This table outlines the selection process for the sample. 
Table 2: Descriptive Statistics

\begin{tabular}{lcccccc}
\hline Variable & $\mathrm{N}$ & Mean & Std. Dev. & $\mathrm{p}(25)$ & Median & $\mathrm{p}(75)$ \\
\hline TargetSwitch $_{t}$ & 27,644 & 0.005 & 0.074 & 0.000 & 0.000 & 0.000 \\
OtherSwitch $_{t}$ & 27,644 & 0.075 & 0.263 & 0.000 & 0.000 & 0.000 \\
OOpInc $_{t+2, t}$ & 27,644 & -0.009 & 0.225 & -0.049 & -0.001 & 0.041 \\
AOpCF $F_{t+2 . t}$ & 27,644 & -0.007 & 0.190 & -0.054 & -0.002 & 0.047 \\
Age $_{t}$ & 27,644 & 20.260 & 15.623 & 8.000 & 15.000 & 27.000 \\
Cash $_{t}$ & 27,644 & 0.244 & 0.248 & 0.046 & 0.154 & 0.374 \\
CEOChange $_{t}$ & 27,644 & 0.103 & 0.305 & 0.000 & 0.000 & 0.000 \\
DiscAcc $_{t}$ & 27,644 & 0.147 & 0.313 & 0.021 & 0.052 & 0.125 \\
GoingConcern $_{t}$ & 27,644 & 0.046 & 0.208 & 0.000 & 0.000 & 0.000 \\
Growth $_{t}$ & 27,644 & 0.138 & 0.516 & -0.051 & 0.048 & 0.177 \\
InvRec $_{t}$ & 27,644 & 0.233 & 0.183 & 0.082 & 0.194 & 0.341 \\
Leverage $_{t}$ & 27,644 & 0.214 & 0.286 & 0.003 & 0.151 & 0.326 \\
Loss $_{t}$ & 27,644 & 0.378 & 0.485 & 0.000 & 0.000 & 1.000 \\
M\& $_{t}$ & 27,644 & 0.482 & 0.500 & 0.000 & 0.000 & 1.000 \\
ModOpinion $_{t}$ & 27,644 & 0.368 & 0.482 & 0.000 & 0.000 & 1.000 \\
ROA $_{t}$ & 27,644 & -0.059 & 0.331 & -0.078 & 0.028 & 0.076 \\
Size $_{t}$ & 27,644 & 5.894 & 2.191 & 4.175 & 5.781 & 7.467 \\
& & & & & & \\
\hline
\end{tabular}

This table presents descriptive statistics for the variables in Equation (1). All variables are formally defined in Appendix B. 
Table 3: Correlations

\begin{tabular}{|c|c|c|c|c|c|c|c|c|c|c|c|c|c|c|c|c|c|}
\hline Variable & (1) & (2) & (3) & (4) & (5) & (6) & (7) & $(8)$ & (9) & (10) & (11) & $(12)$ & (13) & (14) & $(15)$ & $(16)$ & (17) \\
\hline (1) TargetSwitch ${ }_{t}$ & 1.00 & & & & & & & & & & & & & & & & \\
\hline (2) OtherSwitch ${ }_{t}$ & -0.02 & 1.00 & & & & & & & & & & & & & & & \\
\hline (3) $\Delta O p \operatorname{Inc} c_{t+2, t}$ & 0.01 & -0.01 & 1.00 & & & & & & & & & & & & & & \\
\hline (4) $\triangle O p C F_{t+2, t}$ & 0.01 & -0.01 & 0.69 & 1.00 & & & & & & & & & & & & & \\
\hline (5) $\mathrm{Age}_{t}$ & -0.02 & -0.04 & 0.01 & 0.00 & 1.00 & & & & & & & & & & & & \\
\hline (6) $\mathrm{Cash}_{t}$ & 0.01 & -0.01 & -0.04 & -0.08 & -0.28 & 1.00 & & & & & & & & & & & \\
\hline (7) CEOChange ${ }_{t}$ & -0.01 & 0.00 & 0.00 & 0.00 & 0.01 & 0.02 & 1.00 & & & & & & & & & & \\
\hline (8) $\operatorname{DiscAcc}_{t}$ & 0.01 & 0.02 & -0.02 & -0.03 & -0.09 & 0.20 & 0.02 & 1.00 & & & & & & & & & \\
\hline (9) GoingConcern ${ }_{t}$ & 0.01 & 0.07 & 0.02 & 0.01 & -0.09 & 0.00 & 0.06 & 0.11 & 1.00 & & & & & & & & \\
\hline (10) Growth ${ }_{t}$ & 0.01 & 0.02 & -0.04 & -0.03 & -0.10 & 0.08 & -0.02 & 0.21 & -0.06 & 1.00 & & & & & & & \\
\hline (11) $\operatorname{InvRec}{ }_{t}$ & -0.01 & 0.04 & 0.02 & 0.06 & 0.10 & -0.33 & -0.01 & -0.06 & -0.03 & -0.09 & 1.00 & & & & & & \\
\hline (12) Leverage $_{t}$ & -0.01 & 0.01 & 0.09 & 0.10 & 0.04 & -0.28 & 0.02 & 0.04 & 0.19 & -0.04 & -0.08 & 1.00 & & & & & \\
\hline (13) $\operatorname{Loss}_{t}$ & 0.00 & 0.07 & 0.10 & 0.06 & -0.27 & 0.28 & 0.08 & 0.14 & 0.24 & -0.07 & -0.13 & 0.08 & 1.00 & & & & \\
\hline (14) $M \& A_{t}$ & 0.00 & -0.03 & 0.02 & 0.02 & 0.07 & -0.25 & -0.01 & -0.10 & -0.11 & 0.07 & 0.02 & 0.03 & -0.17 & 1.00 & & & \\
\hline (15) ModOpinion ${ }_{t}$ & 0.00 & 0.01 & 0.02 & 0.01 & 0.01 & -0.09 & 0.00 & -0.05 & 0.26 & -0.05 & -0.03 & 0.10 & 0.03 & 0.07 & 1.00 & & \\
\hline (16) $R O A_{t}$ & 0.00 & -0.06 & -0.17 & -0.12 & 0.19 & -0.29 & -0.08 & -0.22 & -0.36 & 0.03 & 0.16 & -0.17 & -0.54 & 0.16 & -0.06 & 1.00 & \\
\hline (17) Size $_{t}$ & -0.01 & -0.13 & 0.02 & 0.02 & 0.41 & -0.35 & -0.01 & -0.16 & -0.24 & 0.02 & -0.17 & 0.15 & -0.39 & 0.34 & 0.10 & 0.34 & 1.00 \\
\hline
\end{tabular}

This table presents Pearson's pairwise correlation coefficients for the full sample of observations $(\mathrm{N}=27,644)$. Coefficients in bold and italics indicate significance at the ten percent level. All variables are formally defined in Appendix B. 
Table 4: Targeted Auditor Switches and Changes in Operating Performance

\begin{tabular}{|c|c|c|c|}
\hline & & $(1)$ & (2) \\
\hline & $(+/-)$ & $\Delta O p \operatorname{Inc} c_{t+2, t}$ & $\triangle O p C F_{t+2, t}$ \\
\hline \multirow[t]{2}{*}{ TargetSwitch $_{t}$} & + & $0.0174 * * *$ & $0.0162 * * *$ \\
\hline & & $(2.844)$ & (2.338) \\
\hline \multirow{2}{*}{ OtherSwitch ${ }_{t}$} & ? & 0.0009 & -0.0001 \\
\hline & & $(0.531)$ & $(-0.057)$ \\
\hline \multirow[t]{2}{*}{$\mathrm{Age}_{t}$} & & $0.0002 * * *$ & 0.0000 \\
\hline & & (5.689) & $(0.552)$ \\
\hline \multirow{2}{*}{ Cash $_{t}$} & & $-0.0191 * * *$ & $-0.0322 * * *$ \\
\hline & & $(-7.092)$ & $(-10.563)$ \\
\hline \multirow[t]{2}{*}{ CEOChange $_{t}$} & & $-0.0027^{*}$ & -0.0011 \\
\hline & & $(-1.821)$ & $(-0.659)$ \\
\hline \multirow{2}{*}{$\operatorname{DiscAcc}_{t}$} & & -0.0006 & 0.0007 \\
\hline & & $(-0.345)$ & $(0.375)$ \\
\hline \multirow[t]{2}{*}{ GoingConcern $_{t}$} & & 0.0039 & $-0.0112 * * *$ \\
\hline & & (1.554) & $(-3.872)$ \\
\hline \multirow[t]{2}{*}{ Growth $_{t}$} & & $-0.0077 * * *$ & $-0.0018^{*}$ \\
\hline & & $(-8.345)$ & $(-1.699)$ \\
\hline \multirow[t]{2}{*}{$\operatorname{Inv} \operatorname{Rec}_{t}$} & & 0.0014 & $0.0321 * * *$ \\
\hline & & $(0.394)$ & $(7.854)$ \\
\hline \multirow[t]{2}{*}{ Leverage $_{t}$} & & $-0.0034 *$ & $0.0034 *$ \\
\hline & & $(-1.889)$ & $(1.662)$ \\
\hline \multirow[t]{2}{*}{$\operatorname{Loss}_{t}$} & & $0.0091 * * *$ & $0.0086 * * *$ \\
\hline & & $(7.735)$ & $(6.414)$ \\
\hline \multirow[t]{2}{*}{$M \& A_{t}$} & & 0.0013 & 0.0012 \\
\hline & & $(1.258)$ & (1.002) \\
\hline \multirow[t]{2}{*}{ ModOpinion $_{t}$} & & 0.0013 & 0.0019 \\
\hline & & $(1.110)$ & $(1.484)$ \\
\hline \multirow[t]{2}{*}{$R O A_{t}$} & & $-0.1806 * * *$ & $-0.1027 * * *$ \\
\hline & & $(-100.595)$ & $(-50.442)$ \\
\hline \multirow[t]{2}{*}{ Size $_{t}$} & & $0.0022 * * *$ & $0.0020 * * *$ \\
\hline & & $(7.258)$ & $(5.948)$ \\
\hline Industry FE / Year FE & & Yes & Yes \\
\hline TargetSwitch $_{t}>$ OtherSwitch ${ }_{t}$ & & $6.83 * * *$ & $5.23 * *$ \\
\hline Observations & & 27,644 & 27,644 \\
\hline Adjusted R-squared & & 0.392 & 0.132 \\
\hline
\end{tabular}

This table presents the results of robust regression estimations of Equation (1). The dependent variable in Column (1) is $\Delta O$ In $_{t+2, t}$, and the dependent variable in Column (2) is $\triangle O p C F_{t+2, t}$. All variables are formally defined in Appendix B. Industry and year specific coefficients are not included for brevity, and t-statistics are presented in parentheses below the coefficient estimates. *, **, and *** indicate significance at the $0.10,0.05$, and 0.01 levels, respectively (one-sided tests of significance for variables with a predicted direction and two-sided tests otherwise). 
Table 5: Cross-Sectional Analyses

\begin{tabular}{|c|c|c|c|c|c|c|c|c|c|}
\hline & $(+/-)$ & $\frac{(1)}{\Delta O p I n c_{t+2, t}}$ & $\begin{array}{c}(2) \\
\Delta O p C F_{t+2, t}\end{array}$ & $\frac{(3)}{\Delta O p \operatorname{Inc} c_{t+2, t}}$ & $\begin{array}{c}(4) \\
\Delta O p C F_{t+2, t}\end{array}$ & $\begin{array}{c}(5) \\
\Delta O p \operatorname{Inc} c_{t+2, t}\end{array}$ & $\begin{array}{c}(6) \\
\Delta O p C F_{t+2, t}\end{array}$ & $\begin{array}{c}(7) \\
\Delta O p \operatorname{Inc} c_{t+2, t}\end{array}$ & $\begin{array}{c}(8) \\
\Delta O p C F_{t+2, t}\end{array}$ \\
\hline TargetSwitch ${ }_{t}$ & & $\begin{array}{l}-0.0056 \\
(-0.498)\end{array}$ & $\begin{array}{l}-0.0101 \\
(-0.799)\end{array}$ & $\begin{array}{l}0.0063 \\
(0.765)\end{array}$ & $\begin{array}{l}0.0051 \\
(0.540)\end{array}$ & $\begin{array}{c}0.0287 * * * \\
(2.846)\end{array}$ & $\begin{array}{c}0.0198^{*} \\
(1.756)\end{array}$ & $\begin{array}{l}0.0103 \\
(1.434)\end{array}$ & $\begin{array}{l}0.0055 \\
(0.680)\end{array}$ \\
\hline TargetSwitch $_{t} *$ IndConc $_{t}$ & + & $\begin{array}{c}0.3502 * * \\
(2.244)\end{array}$ & $\begin{array}{c}0.4427 * * * \\
(2.502)\end{array}$ & & & & & & \\
\hline IndConc $t_{t}$ & & $\begin{array}{c}0.1199 * * * \\
(4.559)\end{array}$ & $\begin{array}{c}0.1303 * * * \\
(4.371)\end{array}$ & & & & & & \\
\hline TargetSwitch $_{t} *$ Enforce $_{t}$ & + & & & $\begin{array}{c}0.0236 * * \\
(1.929)\end{array}$ & $\begin{array}{c}0.0264 * * \\
(1.901)\end{array}$ & & & & \\
\hline Enforce $_{t}$ & & & & $\begin{array}{c}0.0025 * * * \\
(2.653)\end{array}$ & $\begin{array}{l}0.0007 \\
(0.616)\end{array}$ & & & & \\
\hline TargetSwitch $_{t} *$ HighLiab $_{t}$ & - & & & & & $\begin{array}{c}-0.0358 * * * \\
(-2.502)\end{array}$ & $\begin{array}{c}-0.0232 * \\
(-1.452)\end{array}$ & & \\
\hline HighLiab $_{t}$ & & & & & & $\begin{array}{c}-0.0022^{*} \\
(-1.663)\end{array}$ & $\begin{array}{l}0.0023 \\
(1.564)\end{array}$ & & \\
\hline TargetSwitch $_{t} *$ InvIntens $t$ & + & & & & & & & $\begin{array}{c}0.0892 * * \\
(1.760)\end{array}$ & $\begin{array}{c}0.1535 * * * \\
(2.673)\end{array}$ \\
\hline InvIntens $_{t}$ & & & & & & & & $\begin{array}{c}0.0134 * * \\
(1.989)\end{array}$ & $\begin{array}{c}-0.0851 * * * \\
(-11.150)\end{array}$ \\
\hline Controls & & Yes & Yes & Yes & Yes & Yes & Yes & Yes & Yes \\
\hline Industry FE / Year FE & & Yes & Yes & Yes & Yes & Yes & Yes & Yes & Yes \\
\hline Observations & & 27,644 & 27,644 & 27,644 & 27,644 & 16,760 & 16,760 & 27,644 & 27,644 \\
\hline Adjusted R-squared & & 0.393 & 0.134 & 0.393 & 0.133 & 0.369 & 0.162 & 0.393 & 0.137 \\
\hline
\end{tabular}

This table presents the results of robust regression estimations of several modified forms of Equation (1). Columns (1) and (2) present the results with the inclusion of IndConc $c_{t}$ and the interaction of TargetSwitch ${ }_{t}$ and IndConc $c_{t}$ as additional explanatory variables, Columns (3) and (4) present the results with the inclusion of Enforce $t_{t}$ and the interaction of TargetSwitch ${ }_{t}$ and Enforce ${ }_{t}$ as additional explanatory variables, Columns (5) and (6) present the results with the inclusion of HighLiab ${ }_{t}$ and the interaction of TargetSwitch ${ }_{t}$ and HighLiab $b_{t}$ as additional explanatory variables, and Columns (7) and (8) present the results with the inclusion of InvIntens $s_{t}$ and the interaction of TargetSwitch ${ }_{t}$ and InvIntens $s_{t}$ as additional explanatory variables. All variables are formally defined in Appendix B. Only the coefficients of interest are reported for brevity, and t-statistics are presented in parentheses below the coefficient estimates. *, **, and $* * *$ indicate significance at the $0.10,0.05$, and 0.01 levels, respectively (one-sided tests of significance for variables with a predicted direction and two-sided tests otherwise). 
Table 6: Test of Auditor-Client Realignments

\begin{tabular}{|c|c|c|c|c|}
\hline & & (1) & & (2) \\
\hline & $(+/-)$ & $\begin{array}{l}\text { Switch to Local } \\
\text { Market Auditor }_{t}\end{array}$ & $(+/-)$ & $\begin{array}{c}\text { Switch to Non-Local } \\
\text { Market Auditor }\end{array}$ \\
\hline MarketSwitch $h_{t-1}$ & + & $\begin{array}{l}0.3015 * * * \\
(4.009)\end{array}$ & $?$ & $\begin{array}{c}-0.2334 * * * \\
(-3.159)\end{array}$ \\
\hline $\operatorname{Age}_{t-1}$ & & $\begin{array}{l}0.0010 \\
(0.368)\end{array}$ & & $\begin{array}{l}0.0036 \\
(1.306)\end{array}$ \\
\hline $\operatorname{Cash}_{t-1}$ & & $\begin{array}{l}-0.2866 \\
(-1.624)\end{array}$ & & $\begin{array}{c}-0.7899 * * * \\
(-4.237)\end{array}$ \\
\hline CEOChange $_{t-1}$ & & $\begin{array}{l}0.0072 \\
(0.062)\end{array}$ & & $\begin{array}{c}0.2622 * * \\
(2.341)\end{array}$ \\
\hline $\operatorname{DiscAcc} t-1$ & & $\begin{array}{l}-0.0140 \\
(-0.133)\end{array}$ & & $\begin{array}{l}0.1267 \\
(1.181)\end{array}$ \\
\hline GoingConcern $_{t-1}$ & & $\begin{array}{c}0.2666^{*} \\
(1.833)\end{array}$ & & $\begin{array}{l}0.5670^{* * * *} \\
(4.161)\end{array}$ \\
\hline Growth $_{t-1}$ & & $\begin{array}{l}0.0525 \\
(1.242)\end{array}$ & & $\begin{array}{c}0.0853 * * \\
(2.057)\end{array}$ \\
\hline $\operatorname{InvRec}_{t-1}$ & & $\begin{array}{l}0.2313 \\
(0.981)\end{array}$ & & $\begin{array}{l}0.1264 \\
(0.581)\end{array}$ \\
\hline Leverage $_{t-1}$ & & $\begin{array}{l}-0.1825 \\
(-1.432)\end{array}$ & & $\begin{array}{l}0.0497 \\
(0.474)\end{array}$ \\
\hline $\operatorname{Loss}_{t-1}$ & & $\begin{array}{l}0.2471 * * * \\
(3.301)\end{array}$ & & $\begin{array}{c}0.1909^{* *} \\
(2.375)\end{array}$ \\
\hline$M \& A_{t-1}$ & & $\begin{array}{l}0.0167 \\
(0.238)\end{array}$ & & $\begin{array}{l}0.0926 \\
(1.234)\end{array}$ \\
\hline ModOpinion $_{t-1}$ & & $\begin{array}{l}0.2380 * * * \\
(3.089)\end{array}$ & & $\begin{array}{l}0.0885 \\
(1.030)\end{array}$ \\
\hline$R O A_{t-1}$ & & $\begin{array}{c}-0.1439^{*} \\
(-1.880)\end{array}$ & & $\begin{array}{c}0.2038^{* *} \\
(1.962)\end{array}$ \\
\hline Size $_{t-1}$ & & $\begin{array}{c}-0.0935 * * * \\
(-4.335)\end{array}$ & & $\begin{array}{c}-0.4158 * * * \\
(-16.963)\end{array}$ \\
\hline Expert $_{t-1}$ & & $\begin{array}{c}-0.2240 * * * \\
(-3.344)\end{array}$ & & $\begin{array}{l}0.0610 \\
(0.846)\end{array}$ \\
\hline Mismatch $_{t-1}$ & & $\begin{array}{l}0.2247 * * * \\
(2.791)\end{array}$ & & $\begin{array}{c}0.1358^{*} \\
(1.685)\end{array}$ \\
\hline Tenure $_{t-1}$ & & $\begin{array}{c}0.0319 * * \\
(2.192)\end{array}$ & & $\begin{array}{c}-0.0413 * * * \\
(-2.758)\end{array}$ \\
\hline Industry FE / Year FE & \multicolumn{4}{|c|}{ Yes } \\
\hline $\begin{array}{l}\text { Observations } \\
\text { Pseudo R-squared }\end{array}$ & \multicolumn{4}{|c|}{$\begin{array}{c}27,644 \\
0.100\end{array}$} \\
\hline
\end{tabular}

This table presents the results of a multinomial logistic regression estimation with companies that do not switch auditors in period $t$ serving as the reference group. Column (1) reports the results for switches to a local market auditor in period $t$, and Column (2) reports the results for switches to a non-local market auditor in period $t$. All variables are formally defined in Appendix B. Industry and year specific coefficients are not included for brevity, and z-statistics are presented in parentheses below the coefficient estimates. ${ }^{*}, *$, and $* * *$ indicate significance at the $0.10,0.05$, and 0.01 levels, respectively (one-sided tests of significance for variables with a predicted direction and two-sided tests otherwise). 


\section{Table 7: Targeted Auditor Switches and Audit Pricing}

\begin{tabular}{|c|c|c|c|c|c|c|}
\hline \multirow[b]{2}{*}{ Variable } & \multicolumn{2}{|c|}{ TargetSwitch $_{t}=1$} & \multicolumn{2}{|c|}{ TargetSwitch $_{t}=0$} & \multirow[b]{2}{*}{ Difference } & \multirow[b]{2}{*}{ t-test } \\
\hline & $\mathrm{N}$ & Mean & $\mathrm{N}$ & Mean & & \\
\hline \multirow[t]{2}{*}{$\mathrm{AbnFee}_{t}$} & 151 & 0.123 & 27,493 & -0.004 & 0.127 & $2.21 * *$ \\
\hline & \multicolumn{2}{|c|}{ TargetSwitch $_{t}=1$} & \multicolumn{2}{|c|}{ Switch $_{t}=0$} & & \\
\hline Variable & $\mathrm{N}$ & Mean & $\mathrm{N}$ & Mean & Difference & t-test \\
\hline \multirow[t]{2}{*}{$\mathrm{AbnFee}_{t}$} & 151 & 0.123 & 25,421 & 0.005 & 0.118 & $2.04 * *$ \\
\hline & \multicolumn{2}{|c|}{ TargetSwitch $_{t}=1$} & \multicolumn{2}{|c|}{ OtherSwitch $_{t}=1$} & & \\
\hline Variable & $\mathrm{N}$ & Mean & $\mathrm{N}$ & Mean & Difference & t-test \\
\hline $\mathrm{AbnFee}_{t}$ & 151 & 0.123 & 2,072 & -0.122 & 0.245 & $4.13^{* * *}$ \\
\hline
\end{tabular}

This table presents the results of comparisons of the mean values of $A b n F e e_{t}$ across companies that make targeted auditor switches $\left(\right.$ TargetSwitch $\left._{t}=1\right)$ and three comparison groups, including all other companies in the sample (TargetSwitch ${ }_{t}=0$ ), companies that do not switch auditors $\left(\right.$ Switch $_{t}=0$ ), and companies that make non-targeted auditor switches $\left(\right.$ OtherSwitch $\left._{t}=1\right)$. Two-sided t-tests of the differences across these groups are reported in the right-side columns of the table. All variables are formally defined in Appendix B. 


\section{Table 8: Targeted Auditor Switches and Auditor Quality}

Panel A: Univariate comparisons

\begin{tabular}{|c|c|c|c|c|c|c|}
\hline \multirow[b]{2}{*}{ Variable } & \multicolumn{2}{|c|}{ TargetSwitch $_{t}=1$} & \multicolumn{2}{|c|}{ TargetSwitch ${ }_{t}=0$} & \multirow[b]{2}{*}{ Difference } & \multirow[b]{2}{*}{ t-test } \\
\hline & $\mathrm{N}$ & Mean & $\mathrm{N}$ & Mean & & \\
\hline AuditorMistRate $_{t}$ & 150 & 0.131 & 27,068 & 0.105 & 0.026 & $3.57 * * *$ \\
\hline & \multicolumn{2}{|c|}{ TargetSwitch $_{t}=1$} & \multicolumn{2}{|c|}{ Switch $_{t}=0$} & & \\
\hline Variable & $\mathrm{N}$ & Mean & $\mathrm{N}$ & Mean & Difference & t-test \\
\hline \multirow[t]{2}{*}{ AuditorMistRate $_{t}$} & 150 & 0.131 & 25,159 & 0.105 & 0.026 & $3.56^{* * *}$ \\
\hline & \multicolumn{2}{|c|}{ TargetSwitch $_{t}=1$} & \multicolumn{2}{|c|}{ OtherSwitch $_{t}=1$} & & \\
\hline Variable & $\mathrm{N}$ & Mean & $\mathrm{N}$ & Mean & Difference & t-test \\
\hline AuditorMistRate $_{t}$ & 150 & 0.131 & 1,909 & 0.104 & 0.027 & $3.52 * * *$ \\
\hline
\end{tabular}

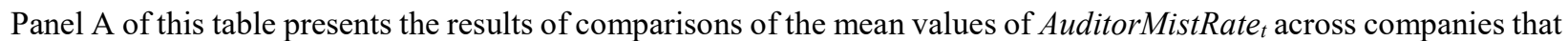
make targeted auditor switches (TargetSwitch $\left.{ }_{t}=1\right)$ and three comparison groups, including all other companies in the sample (TargetSwitch $\left.h_{t}=0\right)$, companies that do not switch auditors $\left(\right.$ Switch $\left._{t}=0\right)$, and companies that make non-targeted auditor switches $\left(\right.$ OtherSwitch $\left._{t}=1\right)$. Two-sided t-tests of the differences across these groups are reported in the rightside columns of Panel A. All variables are formally defined in Appendix B. Panel B presents the results of a robust regression estimation of a modified form of Equation (1), with AuditorMistRate $t_{t}$ as the dependent variable. Industry and year specific coefficients are not included for brevity, and t-statistics are presented in parentheses below the coefficient estimates. $*, * *$, and $* * *$ indicate significance at the $0.10,0.05$, and 0.01 levels, respectively (one-sided tests of significance for variables with a predicted direction and two-sided tests otherwise). 


\section{Table 8 (Continued)}

Panel B: Multiple regression

\begin{tabular}{|c|c|c|}
\hline & & $(1)$ \\
\hline & $(+/-)$ & AuditorMistRate $_{t}$ \\
\hline TargetSwitcht & $?$ & $\begin{array}{l}0.0126 * * \\
(2.035)\end{array}$ \\
\hline OtherSwitch ${ }_{t}$ & $?$ & $\begin{array}{c}-0.0130 * * * \\
(-7.094)\end{array}$ \\
\hline$A g e_{t}$ & & $\begin{array}{c}-0.0003 * * * \\
(-7.988)\end{array}$ \\
\hline $\mathrm{Cash}_{t}$ & & $\begin{array}{l}0.0123 * * * \\
(4.478)\end{array}$ \\
\hline CEOChange $_{t}$ & & $\begin{array}{l}0.0012 \\
(0.820)\end{array}$ \\
\hline $\operatorname{DiscAcc}_{t}$ & & $\begin{array}{l}0.0018 \\
(1.018)\end{array}$ \\
\hline GoingConcern $_{t}$ & & $\begin{array}{c}-0.0085 * * * \\
(-3.268)\end{array}$ \\
\hline Growth $_{t}$ & & $\begin{array}{c}-0.0026 * * * \\
(-2.739)\end{array}$ \\
\hline $\operatorname{InvRec}_{t}$ & & $\begin{array}{l}0.0044 \\
(1.192)\end{array}$ \\
\hline Leverage $_{t}$ & & $\begin{array}{l}0.0033^{*} \\
(1.832)\end{array}$ \\
\hline $\operatorname{Loss}_{t}$ & & $\begin{array}{l}0.0031 * * \\
(2.555)\end{array}$ \\
\hline$M \& A_{t}$ & & $\begin{array}{l}0.0021^{* *} \\
(2.006)\end{array}$ \\
\hline ModOpinion $_{t}$ & & $\begin{array}{c}0.0048 * * * \\
(4.070)\end{array}$ \\
\hline$R O A_{t}$ & & $\begin{array}{l}-0.0019 \\
(-1.027)\end{array}$ \\
\hline Size $_{t}$ & & $\begin{array}{c}0.0060^{* * *} \\
(19.490)\end{array}$ \\
\hline Industry FE / Year FE & & Yes \\
\hline TargetSwitch $_{t}-$ OtherSwitch $h_{t}=0$ & & $15.97 * * *$ \\
\hline $\begin{array}{l}\text { Observations } \\
\text { Adjusted R-squared }\end{array}$ & & $\begin{array}{c}27,218 \\
0.192\end{array}$ \\
\hline
\end{tabular}

